Portland State University

PDXScholar

6-10-1973

\title{
The Bedrock Geology of the Southwest Part of the Kachess Lake Quadrangle, Washington
}

David Carl Lofgren

Portland State University

Follow this and additional works at: https://pdxscholar.library.pdx.edu/open_access_etds

Part of the Geology Commons

Let us know how access to this document benefits you.

\section{Recommended Citation}

Lofgren, David Carl, "The Bedrock Geology of the Southwest Part of the Kachess Lake Quadrangle, Washington" (1973). Dissertations and Theses. Paper 2187.

https://doi.org/10.15760/etd.2184

This Thesis is brought to you for free and open access. It has been accepted for inclusion in Dissertations and Theses by an authorized administrator of PDXScholar. Please contact us if we can make this document more accessible: pdxscholar@pdx.edu. 
AN ABSTRACT OF THE THESIS OF David Carl Lofgren for the Master of Science in Geology presented June 10, 1973.

Title: The Bedrock Geology of the Southwest Part of the Kachess Lake Quadrargle, Washington.

APPROVED BY MEMBERS OF THE THESIS COMMITTEE:

Paul E. Hammond

Gilbert T. Benson

Robert o. Van Atta

The southwestern part of the Kachess Jake quadrangle lies between Lakes Cle Elum and Kachess, on the east flank of the central Cascade Range of Washington. The region lies between the North and South Cascade petrologic provinces, and includes rocks typical of each. Pre-Tertiary Easton Schist (called the Shuksan suite farther north), and the Late Cretaceous-Paleocene Swauk Formation occur widely in the North Cascades, while the Tertiary Silver Pass Volcanics and Teanaway Basalt are typica] of South Cascade 
volcanic sequences. Diabasic dikes of the Teanaway dike swarm occlu throughout the vicinity.

The area is bounded on the west by a major fault, the Kachess, and both folding and faulting hare occurred in the area proper. Folding is represented by southeastplunging Thorp Mountain anticline, to the noxth, and Domexie creek syncline to the south. Several fauits have been recognized, the most important being northwest-southeast trending Thomas Mountain fault, which diagonally bisects the folds and complicates stratigraphio relationships.

The region has been geologicaily active during most of its history. Eugeosynclinal rocks were metamorphosed to blueschists arid greenschists during a late paleozoicweariy Mesozoic orogeny, and folding, faulting, and unconformable relationships involving Tertiary strata indicate continued diastrophism during the Cenozoic. 
THE BEDROCK GEOLOGY OF THE

SOURHWESTERI PART OF THE KACHESS

LAKE QUADRANGLE, WESHINGTON

\author{
by \\ DAVID CARI IOFGREN
}

A thesis submitted in pariial fulitilment of

tha requirements for the degree of

\author{
MASTER OF SCIENCE \\ in \\ GEOLOGY
}

Portland State University

1974 
TO THE OFFICE OF GRADUATE STUDIES AND RESEARCI:

The members of the Committee approve the thesis of David Carl Lofgren presented June 10, 1973.

Paul E. Hammond, Chairman

kobert $\bar{o} \cdot \overline{\text { Van Atta }}$

GilBert m. Benson

Johy D. Beaulieu

APPROVED :

"Richara E. Thoms, Chairman, Departnent of Earth Sciences

Ddvid T. Clark, Dean of Gräduate Studies and Research 
TABLE OF CONTENTS

PAGE

IJIST OF TABIES

v

UIST OF FIGURES

$y i$

LIST OF PLATES

$v i j$

INTRODECTML

1

Purpose of Report

$\dot{I}$

Location and Aoress

1

Regional Geologic Betting

Geograpiy and cimate

3

Previous Work

4

Methods of Study 4

Acknowledgements 5

DESCRIPTIVE GEOLOGY 6

Regional Geologic Relations.

General Stratigraphic Relations 6

Easton Schist $\quad 10$

North Peak Metavolcanics 15

$\begin{array}{ll}\text { Swauk Formation } & 19\end{array}$

Silver Pass Volcanics 25

Diabase Dike SivaIm 35

Taanaway Basalt 41 
DESCRIPTIVE GEOLOGY, CONT.

Roslyn Formation

Howson Andesite 51

STRUCTURAI GEOIOGY

General Relations 53

Folding 53

Faulting 54

GEOLOGIC HISTORY

Introduction $\quad 58$

Summary of Rock Units and Tectonic Everts 58

REFERENCES CITED

APPENDIX A 64

Thin section locations ana hand sample 64 descriptions

APPENDIX B

Petrography of Easton Blueschist 68

APPENDIX C

Petrography of Easton Greenschist 69

APPENDIX D, PART I

Petrography of Silver Pass Volcanics 70

APPENDIX D, PART II

Petrography of Silver Pass volcanics 71

APPENDIX E, PART I

Petrography of Teanaway Basalt

APPENDIX E, PART II

Petrography of Teanaway Basalt 


\section{IIST OF TABLES}

\section{T'ARLE}

PAGE

I Trin section petrographic descriptiors, Silver Pass voicanics

II Thin section petrographic descriptions, Teanaway Basali 


\section{LIST OF FIGURES}

1 Location map of thesis area

2 Correlation chart of geologic formations in Cestral Washington Cascades

Stratigraphic sequence in study area

4 Map location of rock samples studied in thin section

5 Conglamerate in Swauk Formation

6 Contact relations between Siauk Formation,

Easton Schist, and Silver Pass Volcanics 24

Silver Pas Voicanics on Kachess Ridge

9 Columnar section of upper 3600 feet of Silver Pass Volcanics

11 Contact of diabase dike with sandstone of Sweuk Fornation

12 Swauk Formation sandstone enveloped by rock of diabase dike

Teanaway Basalt at south end of Kachess Ridge 


\section{LIST OF PLAMES}

\section{PLATE}

$I$

Bearock geologic map and geologic cross-sections of the southwest part of the Kachess Iake quadrangie, Washington 
INTRODUCTION

\section{Purpose of Peport}

The purpose of this report is to map and describe the bedrock geology of the scuthwestern part of the Wachess Lake guadrangle (15-rin.), Washington, and to interpret the stratigraphic units, structural features, and geologic history of the area.

\section{Iocation and Access}

The Kachess Lake graciraingle is Iocated on the eastexm llank of the Cascade Range of Washington, near the geographical center of the state (Fig. 1). The area mapped embraces 42 square miles in the southwestern part of the quadrangle, between Lakes Cle Elum and Kachess. Commercial logging roaảs and U.S. Forest Service trails leading into the area can be reached from Cle Elum by State Road 2E, along the east shore of Cle Elum Lake, and from the Kachess Lake Road, near the town of Easton.

\section{Regional Geologic setting}

The area lies astride the boundary between the older metamorphic and igneous petrologic province of the northern Cascade Range and the younger volcanic and sedimentary 


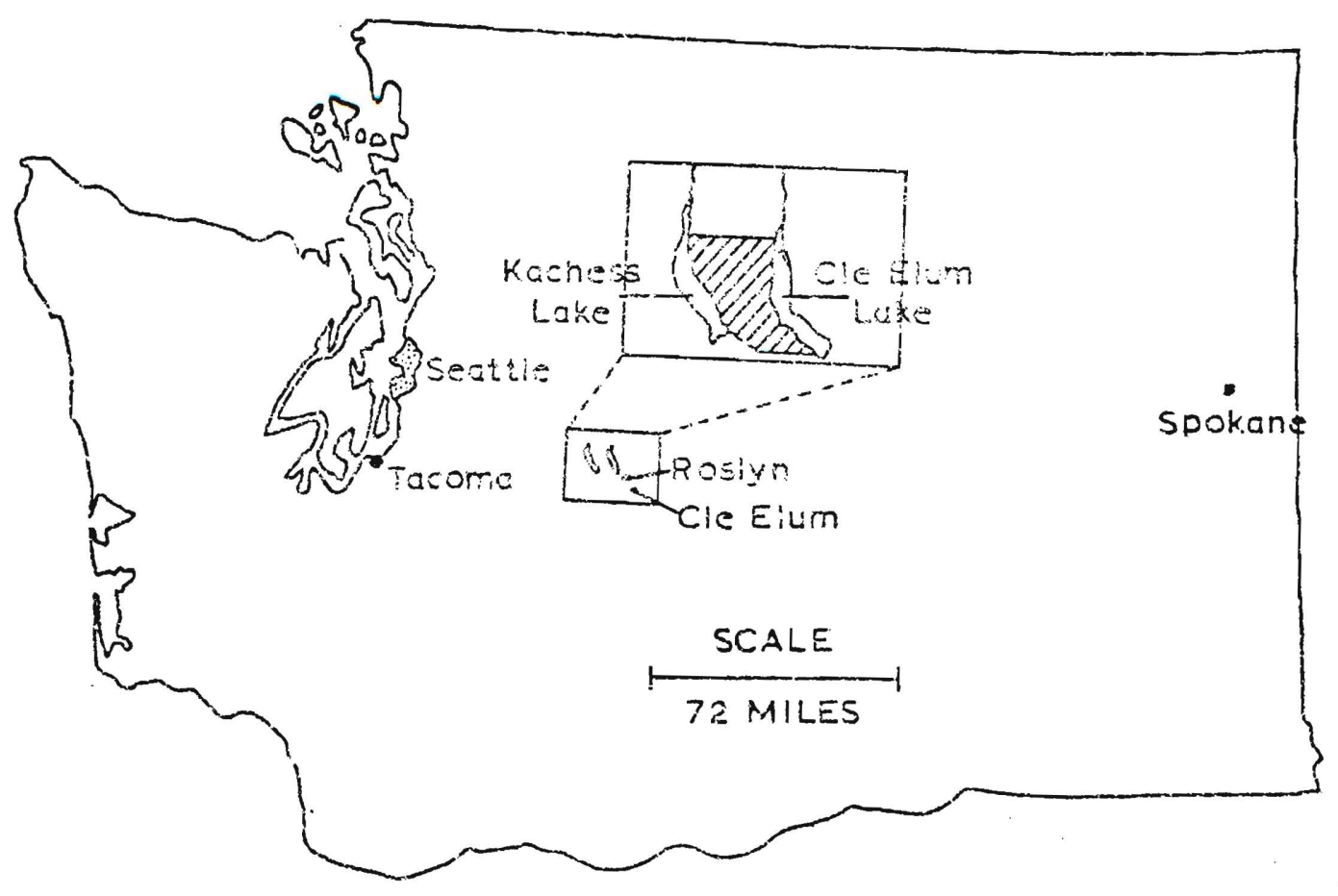

Figure 1. Index map of washington state showing Iocation of thesis area (ruied). 
province of the central and southern Cascades. Rocks and structural features characteristic of both provinces occur in the area and reveal a part of the Paleozoic, Mesozoic, and early Cenozoic geologic history of the washington Cascade Range.

\section{Geography and Climate}

The area is characterized to the south by two neariy parallel northwest-southeast trending ridges (Kachess and (.le glum). Intervening Silver Creek valley provides drainage south to Lake Easton. To the north, individual peaks (such as Thorp Mountain and French Cabin Mountain) prevail over ridges, and drainage is east to Cle Elum Iake by way of Thorp and French Cabin Creeks. Rejief reaches a maximum of 3,649 feet between Thorp Mountain $(5,854$ feet) in the northwest corner of the area, and the Easton airstrip $(2,20.5$ feet) in the southivest corner. Average relief is about 2,500 feet.

winters in the area are typically cold and wet, and summers are warm and dry. At Cle Elum, the average January temperature is 18 degxees and the average july temperature 64 degrees. Average aniual precipitation ranges from approximately 25 inches on the east sicie of the area to approximately 40 inches on the west, mich of which is in the form of snow; consequently, the field season is limited to early June through late october. 
Due to the high annual precipitation, vegetation is moderately thick. Slopes are steep and heavily wooded, and the lack of continuous good outcrops considerably hampers geologic mapping.

\section{Erevious fiork.}

Fioneer geology was done in the area by kussell (3.893; 1899), Smith (1903), and Smith and Calkins (1906), who mapped the central Cascade Range on a reconnaissance scale. Virtualiy no further work was done in the region until Fostex (1960) reinterpreted sore of the earlier investigations in a geologic description of part of the central Cascades. The present work, though enoompassing a relatively $\sin z i$ area, resojves some of the problems encountered by earlier workers, and helps to relate the geology of the central Cascades to that of the northern Cascade Range.

\section{Methods of Study.}

Geology was plotted at a scale of 1:24,000 or U.S. Geological Survey topographic base maps during 8 weeks of field work in the summers of 1971 and 1972 . Field work was supplemented by information obtained from aerial photographs at the scales of $1: 12,000$ and $1: 62,500$ [suxplied by Paul Hammond and by the Northern Facific Railway Co. (now Burlirgton Northern)]. In the laboratory, 
a petrographic microscope was usea to examine thin sections of 45 rock samples. Plagioclase anorthite percentages were determined both by maximurn extinction angles inethod of wichel-Levil and by the extinction of combined carlsbad-albite toirs: (method of F.E. Wright), and optic axia. argles were measured from centered acute-bisectrix interference tigures, using an ocular mictoneter and the chart of A.C. Tobi (1956). A Swift automatic point couriter was used to determina modal compositions of representative slifes. The data obtained from petrographic examination of thin sections is presented in Appendices B-E, ard the hand specimen descriptions and the locations of samples studied are presented in Appendix A and Figure 4.

\section{Acknowledgements}

The writer wishes to thank Professox Paul E. Hammona, advisor for the thesis, for his advice and guidance during the preparation of this report. He also wishes to thank Susan L. Tank for her assistance in typing the first draft of the manuscript, and Gretchen M. Azimzadeh for typing the final draft. Finally, thanks are extended to Daul Harmond and to Burlington Northern, Incorporater for the loan of air photgraphs used in this study. 
DESCRIPTIVE GEOLOGY

\section{Regional Geologic Relations}

The thesis area is bounded on the west by Kachess fault (P1. 1), a major structural feature trending rorth and south through Kachess Lake (Foster, 1960). This fault separates metamorphic, igneous, and sedimentary rocks east of Kachess Lake from a similar, although younger sequence of stratified rocks west of the lake. Foster named the sequence east of the fault the eastern stratigraphic section, and the sequence west of the fault the western stratigraphic section (Fig. 2). This report concerns only rocks of the eastern stratigraphic section (rig. 3) .

\section{General Stratigraphic Relations}

The area is divided by Thomas Mountain fault into a northern, anticlinal block and a southern, synclinal block (P1. 1). Formations of the northern block include the Easton Schist and the North Peak Metavolcanics, which together constitute the pre-Tertiary basement rocks in the area, and the Swauk Formation and the SiIver Pass Volcanics, both of early Tertiary age. Formaticns of the scuthern block include the Silver Pass volcanics, the Teanaway Basalt, and the Roslyn Formation, all of early 


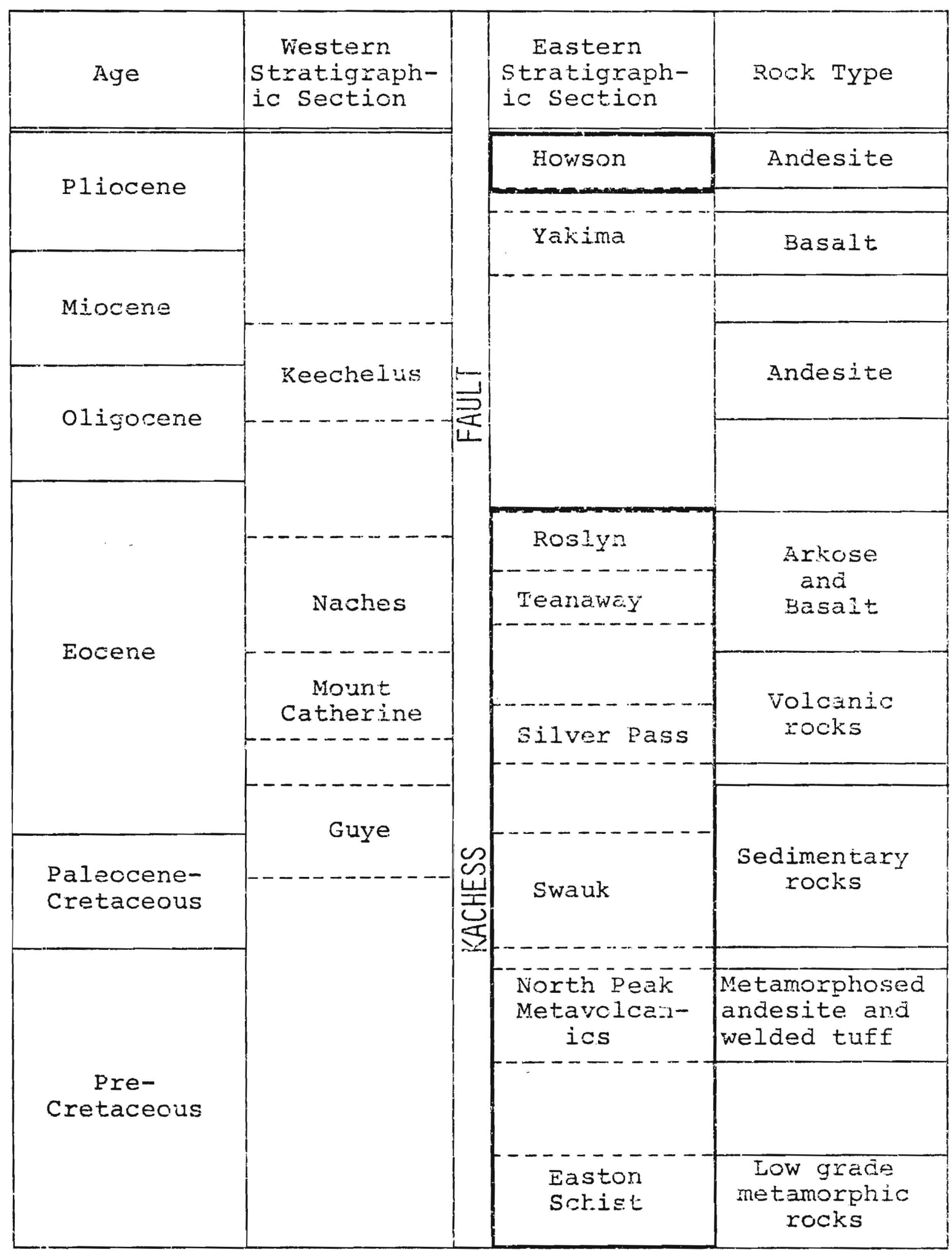

Figure 2. Eastern and western stratigrapinic sections of roster (1960), showing rock units of this report (in bold outline). After Foster (1960), and this report. Not to scale. 


\begin{tabular}{|c|c|c|c|c|c|c|}
\hline \multicolumn{3}{|c|}{ Age } & Eomation & Symbol & $\mathrm{Tk}$ & Brief Description \\
\hline \multirow{6}{*}{ 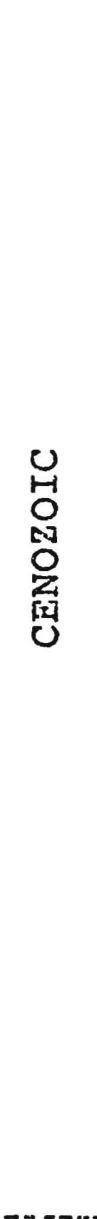 } & \multirow{6}{*}{ 忩 } & \multirow{3}{*}{ 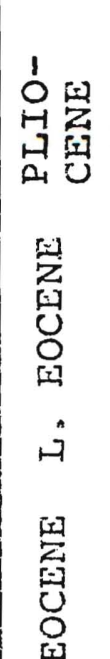 } & 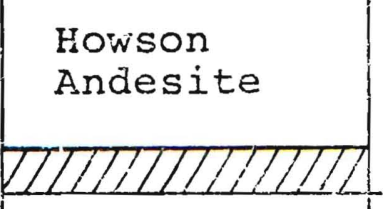 & Tha & $\stackrel{-}{\circ}$ & $\begin{array}{l}\text { Porphyritic horr- } \\
\text { blende andesite }\end{array}$ \\
\hline & & & $\begin{array}{l}\text { Roslyn } \\
\text { Formation }\end{array}$ & Tr & $\frac{i n}{2}$ & Arkosic sandstone \\
\hline & & & 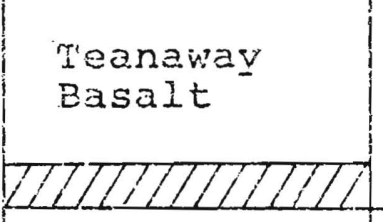 & Ttb & $\begin{array}{l}\dot{0} \\
0 \\
\ddot{*}\end{array}$ & $\begin{array}{l}\text { Basalt lava and } \\
\text { pyroclastic rocks }\end{array}$ \\
\hline & & 空 & $\begin{array}{l}\text { Diabase } \\
\text { Dike } \\
\text { Siarm. }\end{array}$ & Tid & 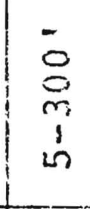 & $\begin{array}{c}\text { Fine to coarse } \\
\text { Grained diabase } \\
\text { dikes }\end{array}$ \\
\hline & & ب & 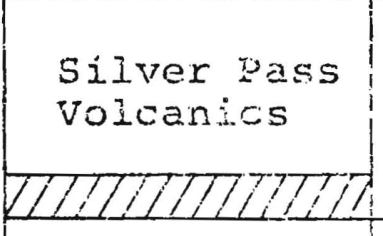 & Tspv & $\begin{array}{l}- \\
0 \\
0 \\
0 \\
1\end{array}$ & $\begin{array}{c}\text { Ancesitic lava } \\
\text { and pyroclastic } \\
\text { rocks }\end{array}$ \\
\hline & & 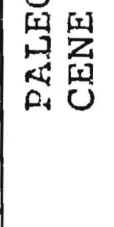 & 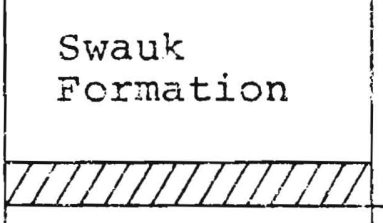 & KTÉ & $\begin{array}{l}0 \\
8 \\
6 \\
6\end{array}$ & $\begin{array}{l}\text { Arkosic sandstone } \\
\text { and conglomerate }\end{array}$ \\
\hline $\begin{array}{l}\text { U } \\
\text { H } \\
\text { N } \\
0 \\
\text { 员 } \\
\text { 壬 }\end{array}$ & 我曷 & & $\begin{array}{l}\text { North Peak } \\
\text { Metavolcan- } \\
\text { ics } \\
\text { MllllllllT }\end{array}$ & pTnp & 8 & $\begin{array}{l}\text { Weakly metamor- } \\
\text { phosed lava, lime- } \\
\text { stone, and tuff }\end{array}$ \\
\hline 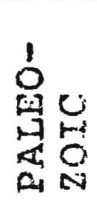 & 否 & & $\begin{array}{l}\text { waston } \\
\text { Schist }\end{array}$ & ple & $\begin{array}{l}0 \\
0 \\
0 \\
0\end{array}$ & $\begin{array}{l}\text { Blueschist, green- } \\
\text { schist and } \\
\text { graphite schist }\end{array}$ \\
\hline
\end{tabular}

Figure 3. Rock linits of Foster's (1960) eastern stratigraphic section that are described in this report (not to scale). Hachure indicates hiatus. See also Figure 2 . 
Tertiary age. Strata of both blocks, with the exception of the Teanaway Basalt and the Roslyn Formation, are intruded by diabase dikes.

The recognition of tise Thomas Mountatis falut was a significant resuit of this study. Earlier workers, who napped at smaller scales, failed to realize its existence, and this lad to misinterpretatiors of certain contact re1.ationships in the area. Smith and Calkins (1906) ard Foster (1960) mapped the Swauk Formation -- Teanaway Basalt contact as an unconformity, and foster (1960) mapped the Silver Pass Volcamics - Teanaway Basalt contact as an unconformity, although he stated $(1960$, p. 106) that the relationship between the silver pass and reanaway strata "may be more complex than the present mapping indicates." As shown in the map (PI. 1), the Swauk Formation is in fault contact with the meanaway Basalt, and, aithough the Teanaway Basalt does unconformably overlie the silver pass Volcanics regionaly, the latter two units are also in local fault contact, complicating their relationship. 


\section{Easton Schist}

\section{Introduction}

The Easton Schist, named by Smith (1903), consists of Jow-grade metamorphic rocks of pre-Tertiary age. It is the oldest formation exposed in the area, forming the basement rocks, and it crops olit extensiveiy to the north of French Cabin Mountain (P1. 1), where it erodes to form gray, humocky slopes and rounded peaks.

\section{I,ithology}

The Easton Schist consists of complexly intercalated blueschist ${ }^{l}$, greenschist, and graphite schist. Blueschist and greenschist are the most common rock-types, with blueschist being somewhat more abundant than greenschist; graphite schist is of lesser occurrence.

The rocks of the Easton Schist display a pronounced northwest-southeast trending foliation (PI.. 1). In general, the greatest schistosity has been developed in the graphite schist and the least in the greenschist,

${ }^{1}$ The term "blueschist", as used in this report, refers to schistose metamorphic rocks containing the blue amphibole glaucophars, and should not be confused with the term "biveschist facies", which is defined (Bailey, in Hyndman, 1972) as those rocks forming within the stabiljty ield of the mineral lawscnite. Lawsonite is not found in blue amphibole-bearing rocks of the area. 
while the biueschist is moderately schistose. No sharp contacts between the blueschist, greenschist, and the graphite schist were observed, and the transition from one rock type to another is gradational.

The blueschist is typically a fine-grained, dark blue rock with a satiny luster. Glaucophane and epidote are the predominart minerais, and occur as segregation iayers developed paralIel to the principal (SI) schistosity pIane. Iayers and lenses of quartz and plagioclase occur locally, and may parallel or cross the principal schistosity plane. Crossite, actinolite, and tremolite have been reported f:rom blueschists of the Easton Schist iFoster, 1960; Stout, 1.964), but were not identified in this study. Detailed retrographic data obtained from the thir section examination of three blueschist samples is presentea in Appendix $B$ of this report. Map locations of the samples studied are shown in Fig. 4.

The greenschist consists predominantiy of clinozoisite, relict plagioclase, and metamorphic plagioclase, the latter mineral occurring as veirs and irregular patches throughout the rock. Foster (1960) and Stout (1964) have reported epidote and actinolite as being the major constituents of both the greenschist and the blueschist, which, by comparison with the composition of rocks in the map area, suggests that the mineraiogy of the Easton Schist is high1.y variable. Data obtained from the petrographic examinafion of two thin sections of the greenschist are presented 


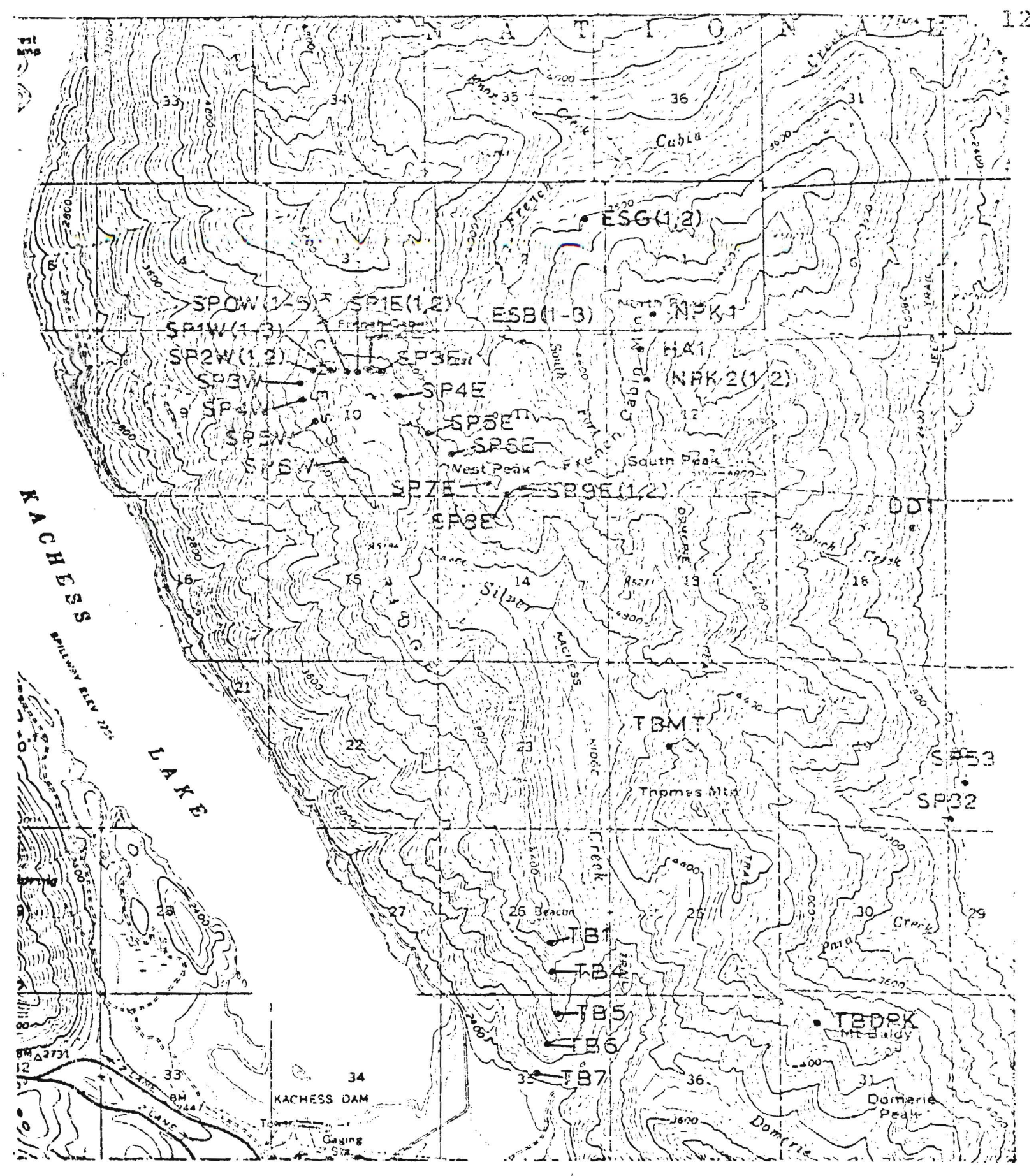

Figure 4. Location map of rock samples studiea in thin section. For explanation of abbreviations, ard hanc sample and petrographic descripticns, see Tables I and II and Appendices $\mathrm{A}-\mathrm{E}$. 
is Appenđix C.

The graphite schist is dull gray in color and fine to medium-grained. Graphite and muscovite are complexly interlayered rith lenticular pods of cucrtz and plagioclase (identified in hand specimen), and the rock is tightiy folded. Foster reports the prasence of minor amounts of chlorite, sericite, and stilpnomelane in the graphite schist.

Relict, unmetamorphosed parent rocks of the Easton Schist. were not found. However, schists rich in epidote and a glaucophane mineral are generally believed to have been derived from basic igneous rocks, and the chemistry of most blueschists and greenschists is similar to that of unmetamorphosed eugeosynclinal rocks (Hyndran, 1972, p. 367). Carbonaceous sediments, from which graphite schist could be derived, might also be found in eugeosynclinal sequences, and the metamorphism of a eugeosynclinal assemblage seems a likely origin for the Easton schist.

\section{Distribution and Thickness}

The Easton Schist crops out in the core of Thcrp Mountain anticline and is at least 8,000 feet thick (PI. I, cross-section $\left.A-A^{\prime}\right)$. The formation is exposed in a smaller fold north of Thorp Mountain anticline, and in an outcrop northwest of the town of Easton (Foster, 1960), as well as (n) the south side of the Yakima Valley (Stout, 1964). Its 
thickness at these localities is unknown.

Arge and Correlation

The Easton Schist is lithologically similar to, and on strike with, netamorphic rocks in the North Cascaües known as the Shuksan suite (Misch, ig66). Together the Easton Schist and the Shuksan suite form a narrow, discontinuous zone of low-grade metamorphic rocks extending northward to near the Canadian border. Blueschists of the Shuksan suite have recently been radiometrically dated at 218 and 259 million years (Misch, 1966). I.f the rocks of the Easton Schist and the Shuksan belt are correlative, and the radiometric dates represent the age of their metamorphism, they can be considered as being late paieozoic to early Mesozoic in age. 
North Peak Metavolcanics

\section{Introduction}

The north peak of French Cabin Mountain is capped by a sequence, approximately 500 feet in thickness (PI. 1, cross-section A), of interlayered metavolcanic rooks and impure martie schist of probable Mesozoic age, These rocks have been described by Smith and Calkins (1906) and Foster (1960), but have never been formally named. Because their occurrence is restricted to North peak, the rocks are referred to in this report as the North Peak Metavolcanics.

\section{Iitholegy}

The metavolcanic rocks consist predominantly of cataclastically deformed volcanic tuff and lithic lapilli tuff. The Iithic lapilli tuff is most abundant, and consists of stretched and compacted lapilii size lithic fragments, as well as anguiar chips of unstrained quartz and altered, untwinned plagioclase. The lithic fragments have been almost completely altered to hematite and chiorite, imparting a mottled, reddish-green color to the rock in hand specimen. Relict pilotaxitic textures of some lithic rragments suggesis their possible derivation from andesitic lavas. A point count of one thin section gave a modal composition for the lithic lapilli tuff of 95 percent lithic 
fragments and 5 percent quartz and feldspar fragments, and chioxitic matrix.

Of lesser abundance than the lapilli tuff, and interlayered with it, is altered volcanic tuff. This rock is schistose, very fine grained, and light greerish gray in color. In thin section it is seen to he composed of broken and stretched plagicclase lathe in a sheared, partiaily recrystalijzed matrix of cuartz, calcite, magnetite, and chloritic material. Brownish streaks, visible in hand specimen, ara beileved to be hematite. Neither the altered lithic lapilii tuff nor the altered volcanic turf can be assigned to a specific grade of metamorphism or metamorphic facies. However, both have suffered cataclastic metamorphism, and are best described as semischists (Turner, in Williams, Turner, and Gilbert, 1954, p. 205).

Intercalated with the metavolcanic rocks are several layers of impure marble schist. This rock is light gray on the fresh surface, has a sugary appearance, and possesses a slight foliation which is emphasized by streaks of red hematite and green chlorite aligned parallel to the direct-ion of foliation. Caicite and clear quartz grains are visible in hand specimen, and Foster (1960) reports the cccurrence of plagioclase in thin section examination.

All of the metamorphic rocks of North Peak have a northwesterly trending foliation. This foliation is parallel to, and believed to be associated with, the 
northwest-southeast trending schistosity in the underlying Easton Schist.

\section{Contact Relations}

The contact of the North Peak Metavolcanics witi the urderlying Easton schist is exposed in the saddle between North Peak and South Peak (PI. 1), where it strikes rorthwesterly and appears to dip steeply to the northeast iPI. 1, cross-section $\mathbb{A}_{-}-\mathrm{A}^{\prime}$ ), and on the ridge or the nortineast side of North Peak (PI. 1), where it strikes northwesterly and is believed to dip steeply to the southwest (PI. I, cross-section $A-A^{\prime}$. Both the northwesterly strike of the exposed contacts and the northwest-trenaing schistosity of the North Peak rocks (p. I6) are parallei to the trend of foliation in the Easton Schist, which suggests that the two units have been deformed simultaneously. Although the trend of the contacts between the two units is evident, it is not known what the nature of the contact is. The contäct may be either depositional or tectonic.

\section{Age and Correlation}

The age of the North Peak Metavolcanics is uncertain. Lithologically, the rocks resemble neither the silver pass Volcanics on near-by west Peak (PI. 1), nor the reanaway Basalt, farther souch on Cle Elum ridge. Smith ana Calkins (1906) assigned them to tre Hawkins cormation of Carbon- 
iferous age, which crops out in the northeast part of the Snoqualmie Quadrangle, though they state that they are "unlike the typical Hawkins greenstone", and Foster (1960) attempts no correlation. Because they are younger than the Easton Schist, of late Paieozoic or early Mesozoic age (p. 14), and because they are more highly deformed than sandstone of the late Cretaceous-Paleocene Swauk Formation, which unconformably overlies Easton Schist on adjacent South Peak (P1. 1), it seems best to consider the North Peak Metavolcanics as Mesozoic in age. 
Swauk Formation

\section{Introduction}

The Swauk Formation, of Upper Cretaceous and Paleocene age, was first described by Russell (1893, 1899), who called it the Swauk Sanastone, and later by Smith (1904) and Smith and Calkins (1906), who introduced the name Swauk Formation. Recently, rocks of the Swalk Formation have been described by Foster (1960). Swauk sedimentary rocks oscur in the northeast part of the map area (EI. I), where they form ridges with steep slopes and rounded crests.

\section{Description}

The Swauk Formation consists primarily of beds of well indurated, medium to coarse-grajned arkosic sandstone, pebble conglomerate, and siltstone, of winch sandstone is the predominant rock type. The sandstone strata are monotonous in character, being typically massive and lacking in distinctive units. The fresh surface is light gray in color, while weathered surfaces may be light yellow, brown, or gray. Quartz, feldspar, and mica are visible in hand specimen. The Swauk is fractured along a northeast and northwest trending rectangular joint system. Bedding planes are not easily distinguished from jointing planes in the massive sandstone, and the accurate determination 
of bedding attitudes in the Swauk Formation is difficult, Leaf imprints, believed to be of a species of palm, were the only fossils found in the sandstone (Pl. 1).

Lenses of conglomerate (Fig. 5) and shale also occur in the formation, and are of lesser abundance thar sandstone. The congiomerate consists of poosly-imbricated, rounced to sub-roundea pobbles of quartzite in a coarsegrained, arkosic matrix. Whe lenses vary in thickness from 2 few inches to several feet and can seldom be traced more than a few tens of feet. Siltstone occurs as firegrained, dark gray to black layers averaging 5 to 20 Teet in thickness and interlayered, light tan colored sanjstone horizons averaging 1 to 3 inches in thickress. No fossils were found in these strata, though carbonaceous material is abundant.

Distribution and Thickness

In the map area, Swauk Formation crops out on the flanks of Thorp Mountain anticline anj at two places along the east shore of Kachess Lake. The formation has a map thickness ${ }^{2}$ of 2545 feet as measured between points $D$ and $D^{\circ}$ iis the area of South Peak (Pl. 1). The thickness is

2 Map thickness, in this report, refers to thicknesses irdirectly obtained by multiplying the map-wiath of the outcrop, neasured perpendicular to the strike, by the sine of: the dip angle of bedding in the outcrop. For further explanation of the method, see Ragan, 1968, p. 10. 


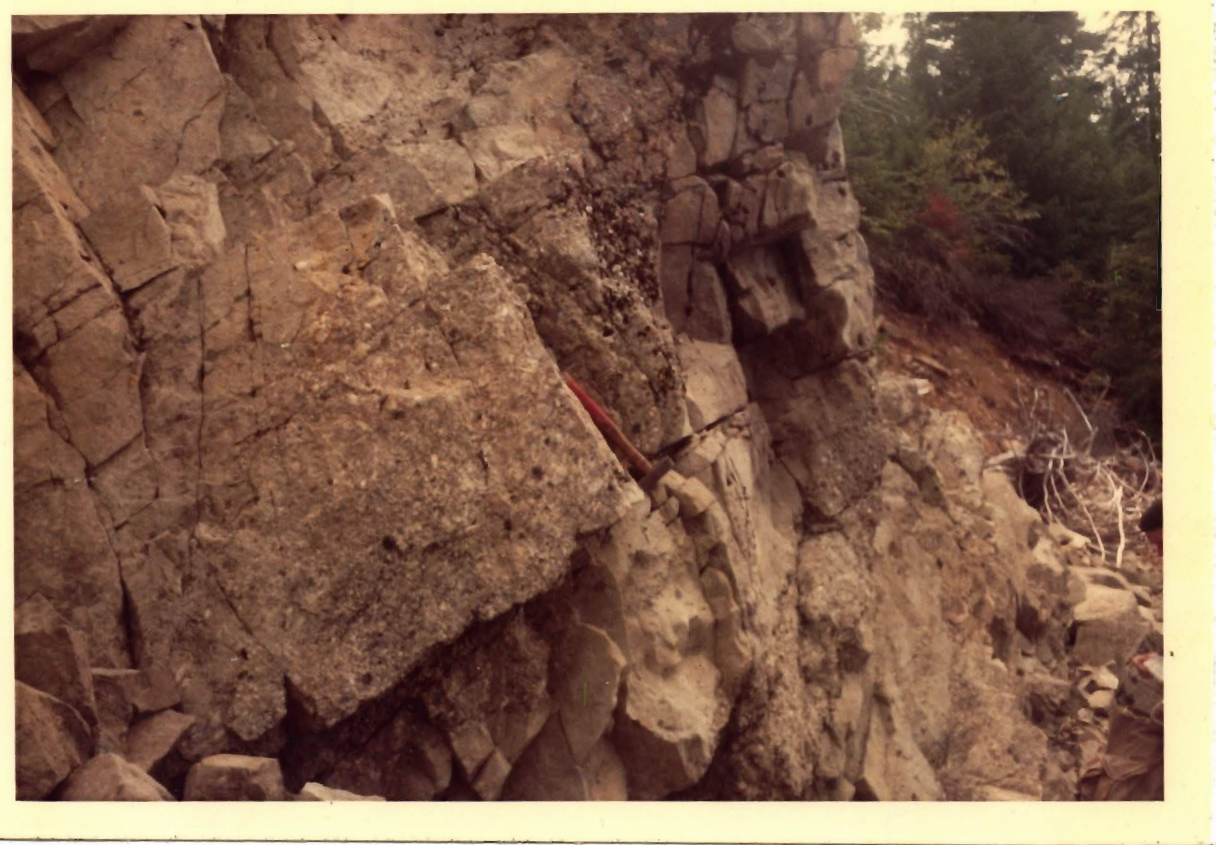

Figure 5. Congloneratic lens in southwesterlydipping swauk sandstone. Outcrop is in Swauk Formation, along west shore of Cle Elurn Lake (SW $1 / 4$ SW $1 / 4$ Sec. 17, T. $21 \mathrm{~N}$, R. 14E.) Hammer for scale. 
highly variable over short distances, however, and ranges from zero feet near the north base of West Peak (PI. I), where the sandstone thins and pinches out (Fig. 6), to about 6600 feet in the area southwest of South Peak (P1. 1, cross-section B-B'l. Regionally, the Swauk is recognized as one of the most extensive formations in the North cascades (Fuster, 1960). Northeast of Leavenworth, it reaches a thickress of 23,000 feet (McKee, 1972).

\section{Depositional Environment}

The sedimentary rocks of the Swauk Formation appear to be non-marine in origin. Fossil palm leaves were found in the area, and leaves representing ferns, conifers, and decidious species have beer reported elsewhere in the Swauk (Mckee, 1972). Fluvial features such as cross-bedding and cut and fill structures occur locally, and these features, together with the relatively thin conglomeratic and silty horizons, and the occurrence of terrestrial leaf fossils, suggest that the deposition of the swauk sediments may have taken place in a deltaic or flood plain environment. Misch (1966) states that the deposition of Swauk Formation sediments occurred on the surface of a rapidly subsiding tectonic trough. A possible source for arkosic sandstone of the swauk is the granitic rock of the Mount Stuart Batholith, northeast of the area (Eriksor, 1973). 
Contact Relations

The Swauk Formation unconformably overlies a metamorphic basement of Easton Schist (Fig. 6). In the area, the basaj. rock is arkosic sandstore, similar to rocks elsewhere in the section. Foster (1960), however, states that the basal. Swauk in most places is shale or siltstone that grades downward into iron-rich laterite, and in some places is conglomerate.

Age and Correlation

As previously noted, the Swauk Formation unconformably overlies the Eastor Schist, of late Paleozoic or early Mesozoic age. It is overiain unconformably by the silvex Pass Volcanics, of probable early Eocene age. The formation is generally considered late cretaceous and Paleocene in age (Foster, 1960; Misch, 1966; McKee, 1972), and in view of the fact that no fossils diagnostic of age were found during the present investigation, a late Cretaceous and Paleocene age is retained in this report.

The Swauk Formation is equivalent to the Chuckanut Formation, also of late Cretaceous ard Paleocene age (Mjoch, 1965; Mckee, 1972). The Chuckanut Formation crops out in the North Cascades and consists of strata of sandstone and conglomerate similar in lithology and thickress to the Swauis Formation (Misch, 1966). 


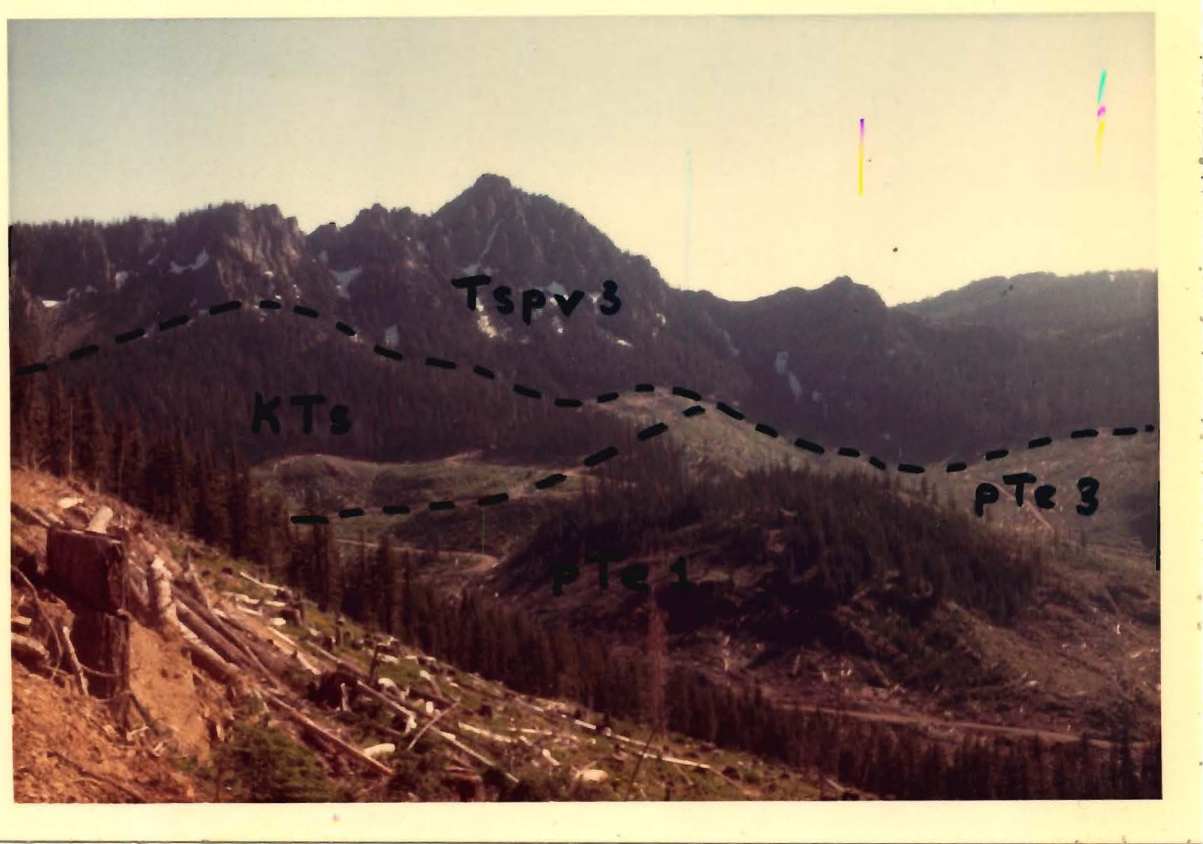

Figure 6. Contact relations between the Swauk Formation (middle ground), the underlying Easton Schist (Knoll in right foreground) and the overlying Silver Pass Volcanics (cliffs in background), in the area of west Peak. Note how strata of the Swauk Formation "pinch out" between the Silver Pass Volcanics and the Easton Schist. View is to southsouthwest from west side of North Peak. 


\section{Silver Pass Voicanics}

\section{Introduction}

The Silver Eass Voicanics, of early Eocene age, were named by Foster (1960) for the seguence of andesitic volcanic and pyroclastic rocks exposed near Silver Pass, at the head of Silver creek (PI. 1). The rocks form steep, rugged cliffs at the north end of Kachess Ridge (Fig. 7), as well as the sharp, west peak of French Cabin Mountain (Fig. 6).

Iithology

The Silver Pass Volcanics consists of light-colored andesitic lava flows, tuff, tuff-breccia, and volcanic breccia. The rocks are light gray or brown in color and have been deeply weathered. At Silver Pass, the type locality, a well-stratified sequence, 3600 feet thick, of interlayered volcanic and pyroclastic rocks is exposed (Figs. 8 and 9; $P I .1$, cross-section $A-A^{\prime}$ ). Three lithologies are predominant in this section; (1) dark-colored, fine-grained aphanitic flow rock, (2) darker, more coarsely... grained porphyritic flow rock, and (3) light colored, highly weathered and altered tuff, lapilli-tuff, and tuff-breccia. Together, the lava flows constitute 2125 feet, or 59 percent of the section, ard the pyroclastic rooks 1475 feet, or 41 


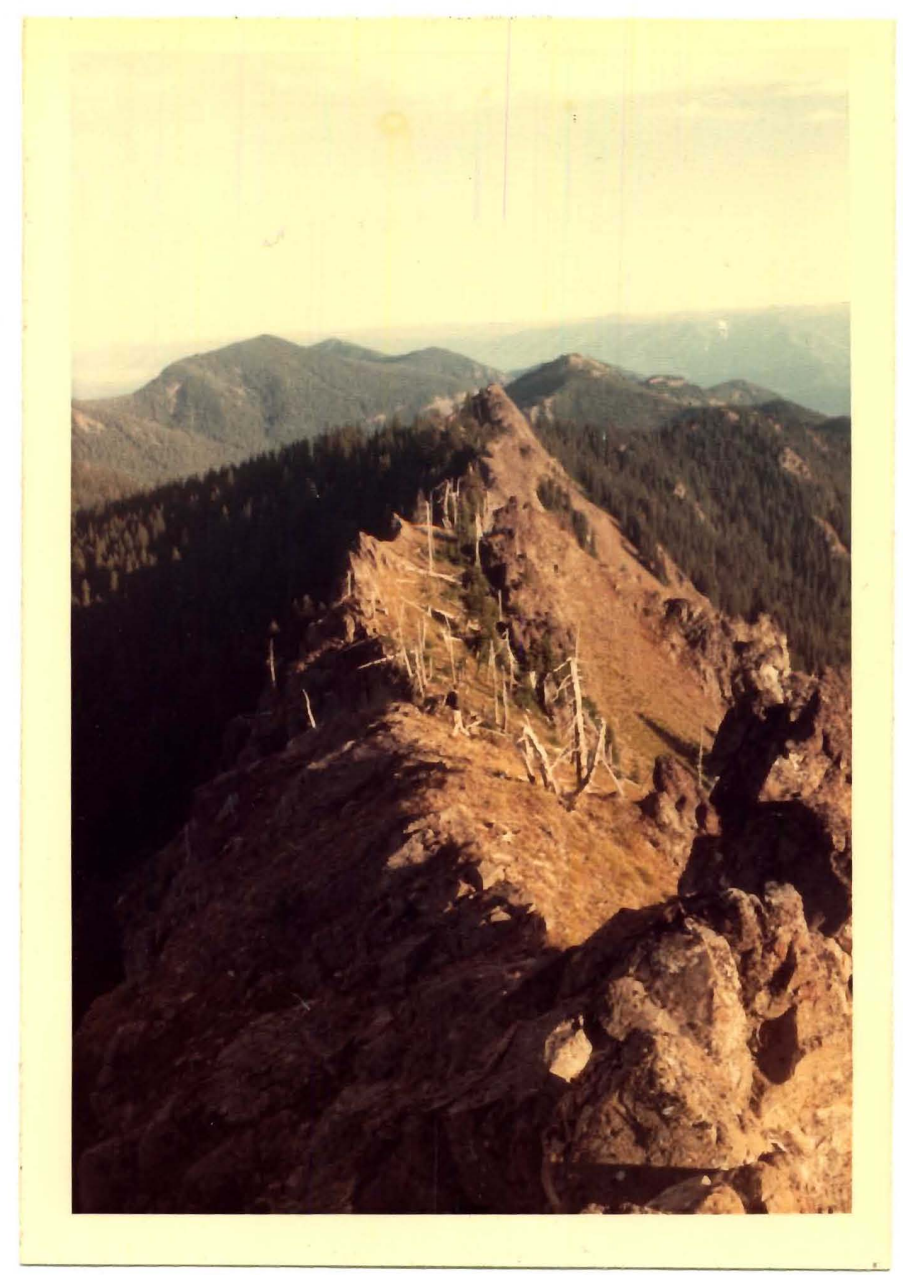

Figure 7. Steep, southwesterly dipping strata of Silver Pass Volcanics, at north end of Kachess Ridge. Peaks in middle background are of Teanaway Basalt, on south side of Thomas Mountain fault, which runs through deep saddle in the upper-left part of the picture. View is to south-southeast from north end of Kachess Ridge. 


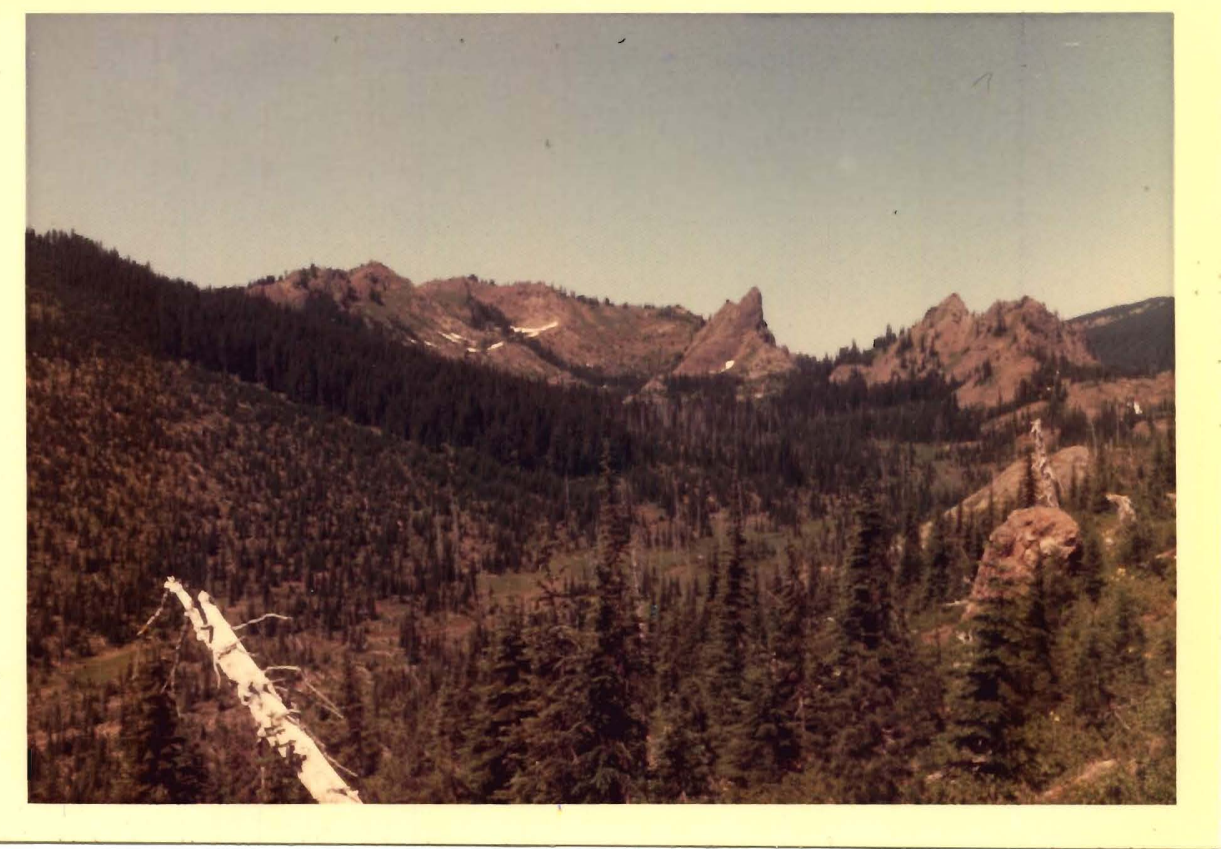

Figure 8. Sequence of stratified westerly-dipping Silver Pass Volcanics exposed in area of Silver Pass. Thickness of section is 3600 feet (Fig. 9). View is to north from south end of brcad, upper Silver Creek Valley. 


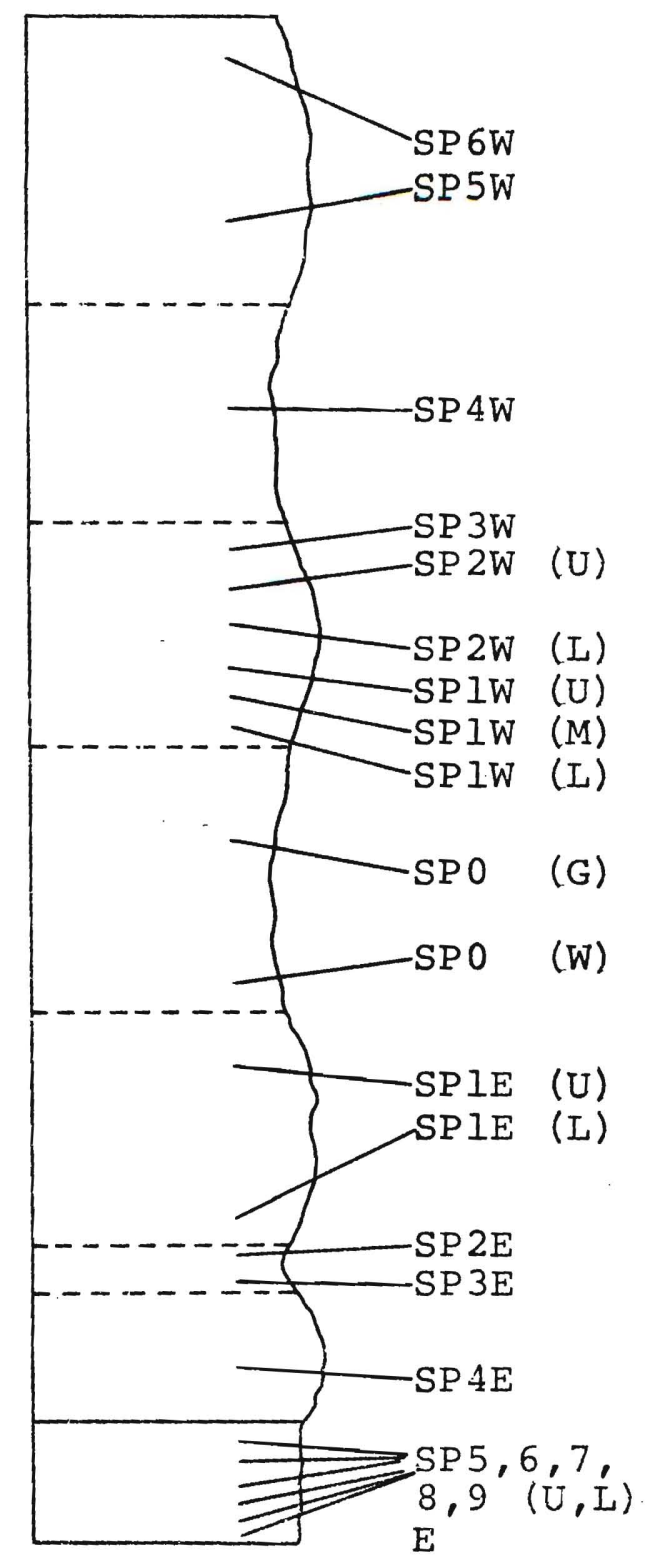

black, aphanitic andesite olive green, porphyritic andesite

Gray-green crystal Iithic lapilli, tuff

porphyritic hornblende andesite brown, vesicular porphyritic andesite

aphanitic hornblende andesite aphanitic hornblende andesite porphyritic augite andesite porphyritic augite hypersthene andesite green, crystal vitric lithic lapilli tuff white, crystal lithic lapilli tuff

porphyritic hornblende andesite aphanitic hornblende andesite

green, crystal lithic lapilli tuff red, vitric crystal lithic lapilli. tuff amygdaloidal lava flow

SP5E, crystal tuff; SP6E - SP9E (U), andesite flows; SP9E (L), volcanic sandstone; total thickness, 2615 feet

Figure 9. Generalized columnar section of upper 3600 feet of Silver Pass Volcanics shown in Fig. 8 . Numbers refer to thin sections examined. For geographic locations of thin sections, see Fig. 4. For detailed petrography, see Table I and Appendix $D$. Except for SP5E - SPSE, column is to scale, 1 inch $=$ 647 feet. 
percent of the section. Petrographic descriptions of these rocks, and of specimens from the underlying, undifferentiated rocks (PI. 1), are presented in Table 1 (p. 30), and the petrography of the formation as a whole is presented summarily in Appendix D (p. 70). Map locations of the samples examined are shown in Figure 4 (p. 12), and the locations by Section, Township, and Range are given in Appendix A (p. 64). A poorly exposed section of Silver Pass Volcanics occurs on the west side of Kachess Ridge, along the east shore of Kachess Lake (PI. 1). These rocks were not examined in thin section, but consist primarily of beds of volcanic breccia several hundred feet thick. The breccia consists of poorly-sorted, angular lithic fragments ranging in size from a few inches to several feet. The fragments consist predominantly of Ijght green or pink, porphyritic volcanic rock and light gray, medium to coarse grained sandstone, as well as occasional clasts of more finely grained sedimentary rock. Some outcrops contain fragments of dense, greenish-black, aphanitic basalt. Where the breccia is well exposed, as it is directly east of, and uphill from, the outcrop of Swauk Formation near the south end of Kachess irake Road (21. 1), it grades upward to lapilli tuff, and finaliy to tuff that appears to have been water-deposited. Thus, the breccia of the Silver Pass Volcanics may be all, or 
TABLE I

PETROGRAPHIC DESCRIPTIONS OF THIN SECTIONS REFERRED TO IN TEXT AND IN FUGURES 4 AND 9. SEE ALSO APPENDIX D.

T.S. Number

Description

SP $6 \mathrm{~W}$

SP $5 W$

$\operatorname{SP} 4 \mathrm{~W}$

SP $3 W$

SP2W (U)

SP $2 W(I)$

SPIW (U)

SPIW (M)

SPIW (L)
Aphanitic andesite containing scattered phenocrysts of zoned, euhedral plagicclase and euhedral to subhedral pyroxene in a pilotaxitic groundmass.

Porphyritic andesite containing altered plagioclase and pyroxene phenocrysts in a holocrystalline, intergranular groundmass.

Crystal lithic lapilli tuff containing broken crystals of plagioclase and quartz, as weil as angular lithic fragments containing plagioclase, pyroxene, and hornblende in a pilotaxitic groundmass.

Porphyritic aphanitic andesite containing phenocrysts of plagioclase and orthopyroxere in a cryptocrystaline groundmass of cuartz and plagioclase.

Parphyritic, vesicular andesite containing phenocrysts of plagioclase and orthoclase (2), as well as glass, calcite, quartz, orthoclase (?), and clay (?) - filled vesicles in a cryptocrystalline matrix.

Aphanitic andesite containing altered phenocrysts of plagioclase and hornblende in a cryptofelsitic groundmass.

Aphanitic andesite containing euhedral hornblende phenocrysts and subhedral augite phenocrysts in a trachytic grounamass.

Porphyritic andesite containing phenocrysts of fresh, subhedral to euhedral twinned augite and altered plagioclase in a brownish-colored, cryptofelsitic groundmass.

Porphyritic pyroxene andesite containing phenocrysts of subhedral to euhearal augite and hypersthene, plus euhedral, normally zoned, slightly altered phenocrysts of 
TABLE I (CONTINUED)

T.S. Number

SPO (W)

$\operatorname{SPIE}(U)$

SPIE (L)

SP2E

$S P 3 E$

$S P 4 E$

SP 5E

$S P \in E$

\section{Description}

plagioclase in a pilotaxitic groundmass.

Light green crystal vitric lithic lapilli tuff containing broken, subhedral to euhedral plagioclase phenocrysts, clear, arcuate glass shards, and lithic fragments having pilotaxitic, subophitic, and cryptofelsitic textures.

White crystal lithic lapilli tuff containing broken plagioclase crystals and stretched and compacted, holocrystalline, pilotaxitic aphanitic lithic fragments in a cryptofelsitic matrix.

Porphyritic andesite containing altered phenocrysts of plagioclase and hornbiende in a cryptofelsitic matrix.

Aphanitic andesite containing partially altered phenocrysts of hornblende and no plagioclase in a cryptofelsitic groundmass.

Iithic lapilli tuff containing rounded, calcite-cemented lithic fragments and quartz chips in a green, cryptocrystalline matrix.

Vitric crystal lithic tuff containing rounded quartz chips and lithic fragments, plus partially deritrified glass fragments, in a matrix of calcite and hematite.

Amygdaloidal lava flow containing numerous, elongate amygdales filled with calcite, quartz, and an unidentified, yellow to yellow-brown fibrous material.

Crystal tuff containing scattered, broken plagioclase crystals in a green, cryptocrystalline matrix.

Porphyritic andesite containing numerous phenocrysts of plagiociase and scattered hornblende phenocrysts in a light green, cryptofelsitic matrix. 
TABLE I (CONTINUED)

T.S. Number

SP 7E

SP 8E

SP9E (U)

SF 9 (L)

\section{Description}

Aphanitic andesite containing flow-oriented plagioclase laths in a light green, trachytic matrix.

Aphanitic andesite containing flow-oriented plagioclase laths in a black, magnetiterich, trachytic matrix.

Aphanitic andesite containing flow-oriented plagioclase laths with occasional larger phenocrysts of plagioclase and hornblende in a green, trachytic groundmass.

Water-lain crystal tuff or volcanic sandstone containing well-sorted, broken, sub-rounded quartz and plagioclase crystals in a green, cryptocrystalline matrix. 
part, sedimentary in origin.

Distribution and Thickness

Silver Pass Volcanics occur on the southwest flank of Thorp Mountain, the west side of Kachess Ridge, the east side of Cle Elum Ridge, and along the south side of Easton Ridge. The thickness of the strata is variable. A thickness of 5800 feet was determined for the strata exposed between the north end of Kachess Ridge and the area east of West Peak (PI. I, cross-sections $A-A^{\prime}$ and $B-B^{\prime}$ ), and a range in thickness of 3100 feet (PI. 1, F-F') to 7990 feet ( $P$ I. $1, E-E^{\prime}$ ) was determined for rocks exposed on the west side of Kachess Ridge. The latter determinations are map thicknesses and assume a constant dip angle in the Silver Pass Volcanics of 70 degrees, the attitude of bedding near the south end of the ridge (PI. I).

\section{Contact Relations}

The Silver Pass Volcanics lie stratigraphically between the underlying Swauk Formation and the overlying Teanaway Basalt. At Silver Pass, the rocks unconformably overlie Easton Schist (PI. 1), and the basal lithology is andesite. To the east, between the south and west peaks of French Cabin Mountain, and on the east side of Cle Elurn Ridge (DI. 1), they overlie Swauk sedimentary rocks with 
an argular discordance of about 10 degrees. Here the basal Silver Pass Volcanics consists of medium-grained sanastone. Examination of a single thin-section of this rock shows it to be composed of subangular to subrourded grains of quartz and plagioclase in a matrix of calci.te and a greenish material, possibly clay. Quartz and plagioclase grains are approximately equal in abundance, vary in size from .2 to $.6 \mathrm{~mm}$, and account for 50 to 60 percent of the rock. Matrix composes the remaining 40 to 50 percent. The thickness of the sandstone, and the nature of the transition to the more typical volcanic and pyroclastic lithology of the Silver Pass Volcanics, is not known.

\section{Age and Correlation}

No fossils have been found in the Silver Pass Volcanics. They unconformably overlie the Swauk Formation of. Upper Cretaceous and Paleocene age (p. 23), and are themselves overlain unconformably by the Teanaway Basalt, of early to middle Eocene age (p. 46); thus, the formation is probably of Paleocene or early Eocene age. 


\section{Diabase Dike Swarm}

\section{Introduction}

A system of north to northeast-trending aibase dikes intrudes rocks of pre-Teanaway basalt age in the map area. The dikes are most numerous in the north-centraI and northeast area of the map (PI. I), and are most conspicuous where they intrude light-colored rocks of the Swauk Formation (Figs. 10, 12). They vary in thickness from a few feet to about 300 feet, are vertical or steepiy dipping, and generally strike in a northeasterly direction. The cikes are best exposed on ridge-crests and slopes, which they tend to bisect, and can seldom be traced farther than the width of the ridge. An exception is the dike exposed along the northeast shore of Cle Elum Lake (PI. 1), which can be traced for nearly a mile.

\section{Li.thology}

The dike rock is typically dark, greenish gray on the fresh surface and weathers to reddish-brown. Textures, in hand specimen, range from fine-grained aphanitic in the outer zones of the dikes to coarse-grained praneritic in their cores. One sample, taken from the center of a dike 300 feet in thickness (Fig, 4, no. DDI) was examined in thin section. The rock is holocrystaliine and contains 53 percent euhedral labradorite (An 46-71), 28 percent 


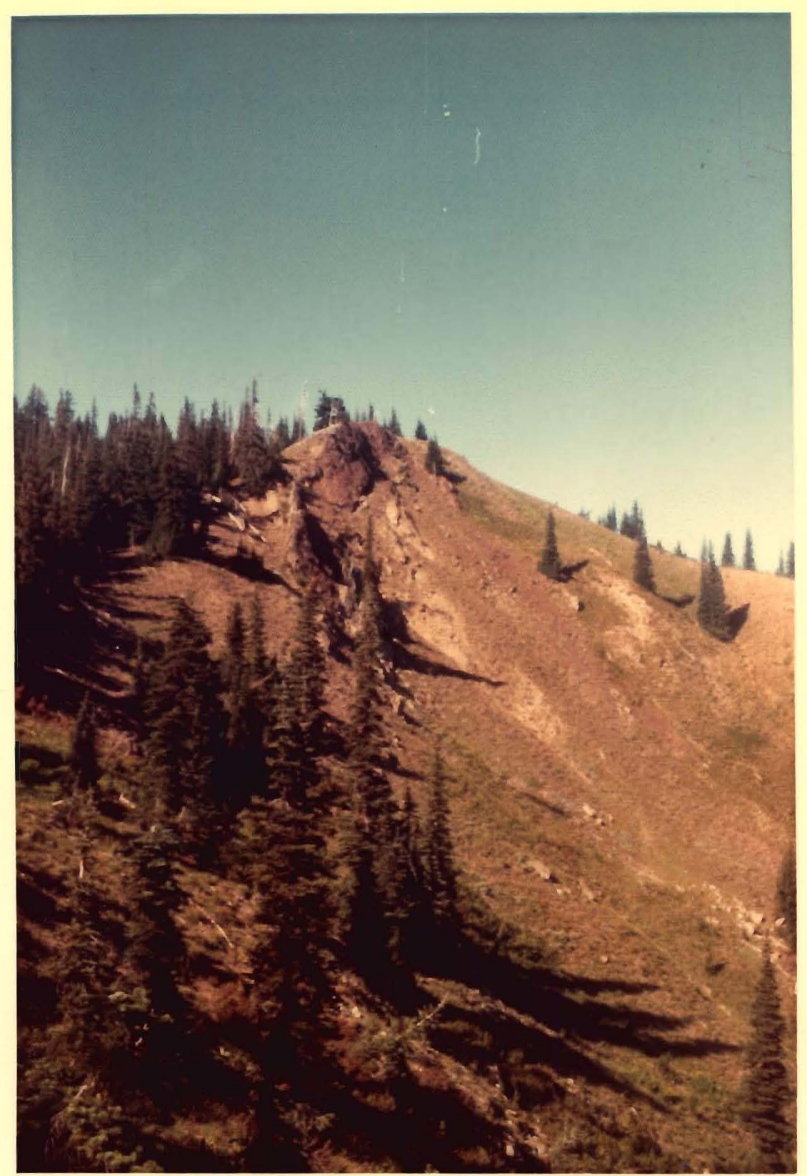

Figure 10. Diabase dike intruding light-colored Swauk sedimentary rocks on Cle Elum Ridge (NE 1/4 NW 1/4 Sec. 13, T2lN, Rl3E). For scale, trees are $30 \mathrm{ft}$. high. 
clear, subophitic augite ( $2 \mathrm{v}=60$ degrees), and 18 percent chloxite, magnetite, and micropegmatite. Scattered, irregular patches of calcite and a fibrous, weakly birefringent material believed to be serpentine occur, and may indicate hydrothermal alteration, possibly of olivine.

Foster (1958) describes a typical, aphanitic dike rock as having intersertal texture and containing 50 percent plagioclase (An 33-50), 30 percent pyroxene (both pigeonite and augite), 15 percent glass, mineraloids, and chloritic material, and 5 percent opaques.

\section{Contact Relations and Alteration}

The dikes intrude rocks of the Easton Schist, the North Peak Metavolcanics, the Swauk Formation, and the Silver Pass Volcanics. Contacts of the dikes with rocks of the Easton Schist and Silver Pass Volcanics were not examined closely, but alteration of the host rocks appears to be minimal. Where the contact with sandstone of the Swavik Formation is observed, it is sharp (Fig. 11), and the sandstone immediately adjacent to the dike has been slightly silicified. On Cle Elum Ridge, large blocks of Swauk. Formation have been entirely surrounded by dike rock (Fig. 12), but have been little altered. The most extensive alteration of rocks intruded by the dikes occurs 


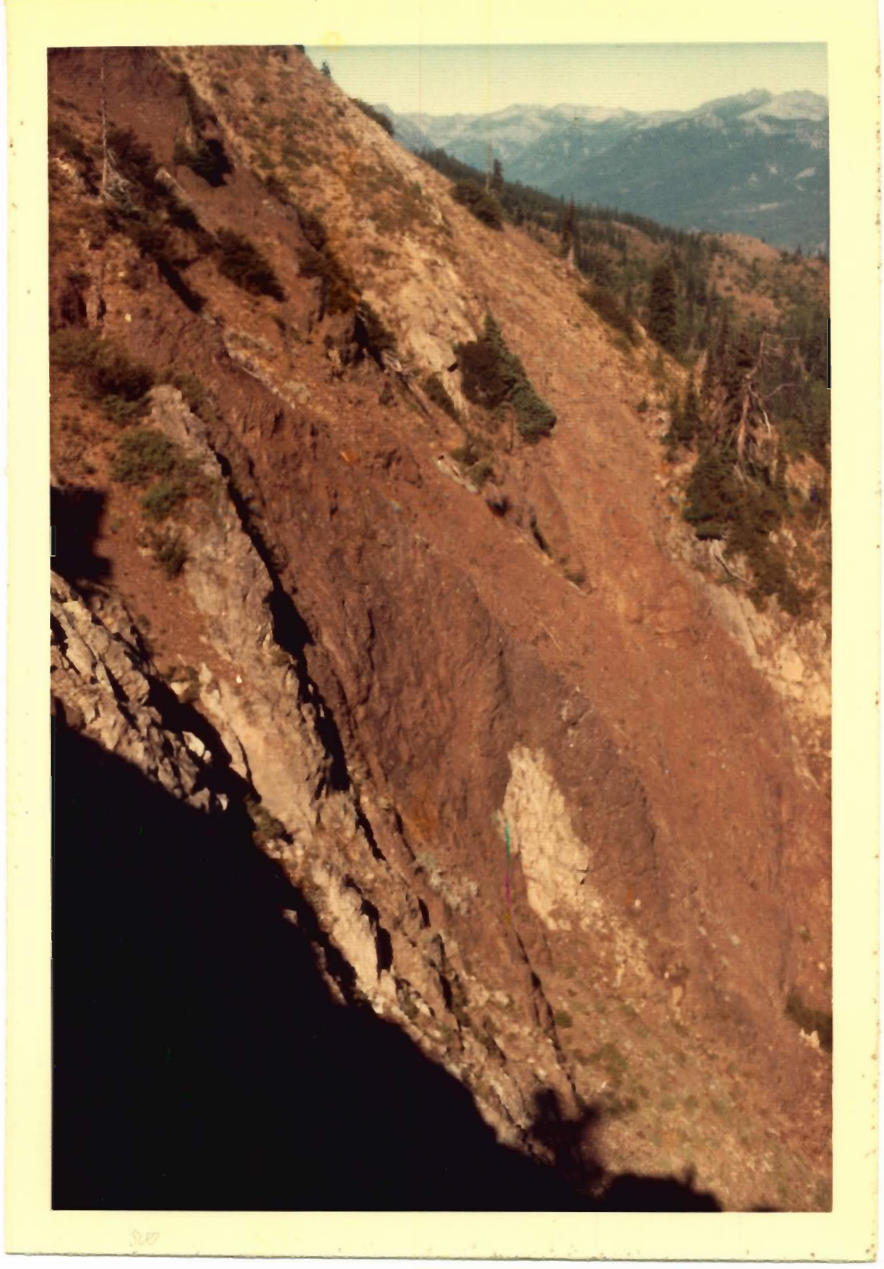

Figure 12. Large block of unaltered Swauk sandstone (lower right-center) enveloped by dike rock. Dike is same as that shown in Fig. 10. 
in the metavolcanic rocks on North Peak. These rocki include metatuffs which consist of red and green-colored lithic fragments that give the rock a mottled, reddishgreen appearance. Where dikes are seen to intrude the metatuff, as along the logging road on the west side of North Peak (PI. 1), the mottled appearance of the host rock completely vanishes within a few inches of the cortact with the dike, and the reddish-green color of the metatuff becomes black. None of the tuffaceous texture remains, and the dense, hornfelsed rock contains numerous veirs of: garnet and hematite.

\section{Age and Correlation}

The youngest rocks intruded by the dikes are those of the Silver Pass Volcanics, of Paleocene or early Eocene age, which suggests an early Eocene age for emplacement of the dikes. Smith and Calkins (1906) mapped dikes similar in trend and lithology to those described here as far eastward as Wenatchee. Foster (1958, 1960) described these dikes and named them the "Teanaway dike swarm". The diabase dikes occurring in the map area are believed to represent the westernmost end of the Teanaway dike swarm. 
Teanaway Basalt

\section{Introduction}

The Teanaway Basalt, of early or middle Eocene age, was named by Smith (1903) for a sequence of basalt lava flows and interbedded pyroclastics exposed along the midale fork of the Teanaway River, east of the map area. Rocks of the formation are highly resistant, forming prominent, steep-sided ridges, and are best exposed at the south end of Kachess Ridge, in a bluff overlooking the town of Easton (Fig. 13).

\section{Iithology}

The Teanaway Basalt consists of flows of dense, black, very fine-grained aphanitic basalt, and pyroclastic rocks composed predominantly of highly altered, poorly sorted fragments of pumice and lava. Both flow rocks and pyroclastics weather reddish-brown, and the strata are contrasted with the gray color of the underlying Silver Pass Volcanics. Bedding in the Teanaway Basalt is thinner and more clearly defined than in the Silver Pass Volcanics or Swauk Formation. The bottom and middle zones of the flows, which average 50 to 100 feet in thickness, consist of greenish or bluish black, aphanitic basalt with few pherocrysts. The upper part of most flows contains a zone of 


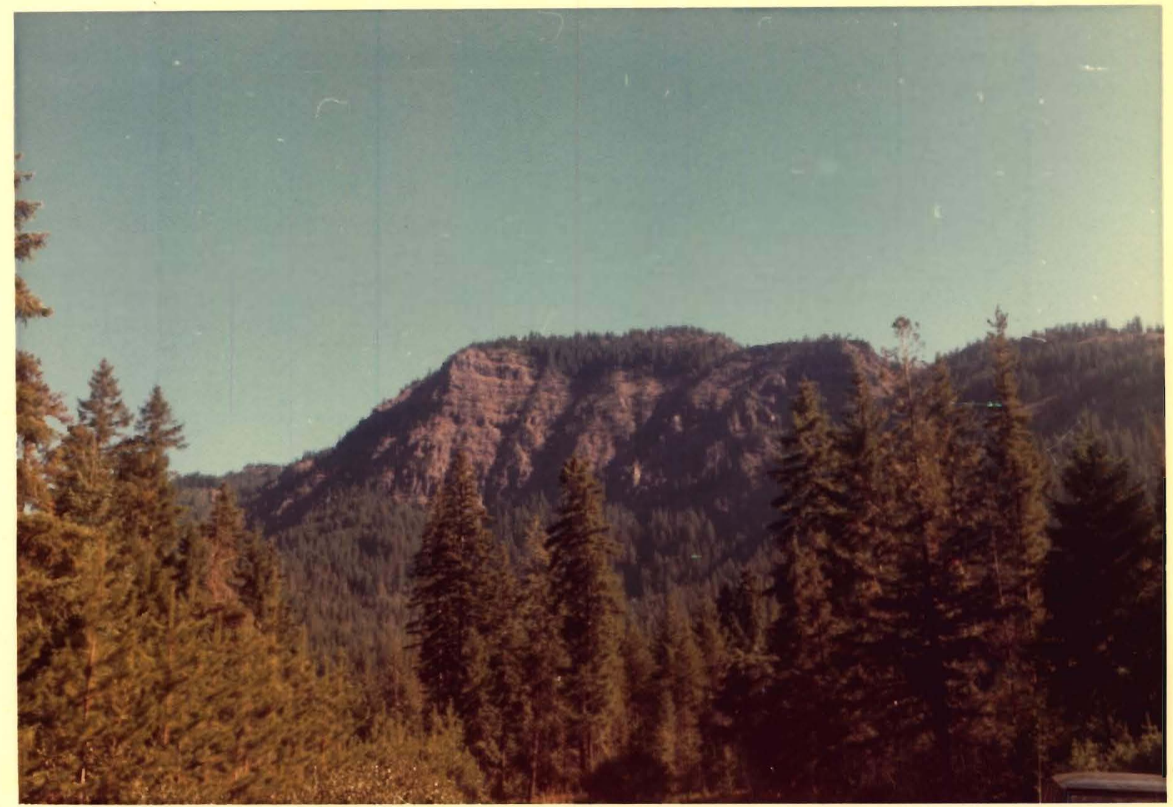

Figure 13: Strata of the Teanaway Basalt exposed at the south end of Kachess Ridge, in bluff overlooking town of Easton. View is to north, from south end of Kachess Lake Road. 
breccia which varies in thickness from a few feet to over 20 feet. The breccia consists of fragments ranging in size from $1 / 2$ inch to 8 inches, which have been cemented together by guartz, and which may be biack, green, or red in color. The breccia zones contain 50-70 percent brecciasize fragments, 30-50 percent lapilli, and 10-30 percent tuff-size fragments (visual estimate). Some of the lava flows, such as the one exposed along the crest at the south end of Kachess Ridge, are amygdaloidal, and contain spherical amygdales of quartz and calcite varying in diameter from one to four inches. The lava flows are highly jointed, and break into rectangular blocks of varying size. Columnar jointing (Fig. 14) and ellipsoidal weathering structures are also present.

Samples of four lava flows and three pyroclastic units were studied in thin section. The thin section descriptions are presented in Table 2 (p. 44), and the petrography of the formation as a whole is summarily described in Appendix E. Sample locations are indicated in Figure 4 (p. 12).

Distribution and Thickness

Teanaway Basalt crops out in the southern half of the map area in the flanks of Cle Elum and Kachess Ridges, which form the limbs of south-plunging Domerie Creek syrcline (P1. 1). The thickest sequence of Teanaway strata 
TABLE II

PETROGRAPHIC DESCRIPTIONS OF THIN SECTIONS REFERRED TO IN TEXT AND IN FIGURE 4. SEE ALSO APPENDIX E.

T.S. Number

Description

TBI

Dense, black, aphanitic basalt containing fresh plagioclase, altered pyroxene, spherulites, and pools of brown glass, in part devitrified, in a pilotaxitic or felted groundmass.

TB4

Dark gray, aphanitic, vesicular basalt containing altered plagioclase microlites and abundant magnetite in a cryptocrystalline matrix of quartz, feldspar, and devitrified glass.

T'B5

Dense, black, aphanitic basalt contairing subhedral plagioclase microlites, subcalcic augite, and magnetite in an intergranular groundmass.

TB6

Green lithic vitric lapilli tuff containing a chaotic assemblage of shattered and altered glass and pumice fragments, as well as highly vesicular, volcanic lithic fragments in a cryptocrystalline matrix of quartz, feldspar and clay.

TB7

Dense, black, aphanitic basalt flow containplagioclase, pyroxene, magnetite, and glass in an intersertal groundmass.

TBDPK

Red-green, crystal lithic tuff, possibly water-lain, containing abundant, severely altered volcanic lithic fragments as well as broken, poorly-sorted crystal fragments of quartz and plagioclase in an opaque groundmass of green clay (?).

TBMT

Light green pumice tuff containing altered and compacted pumice fragments in a matrix of partially to completely devitrified glass and green clay (?). 


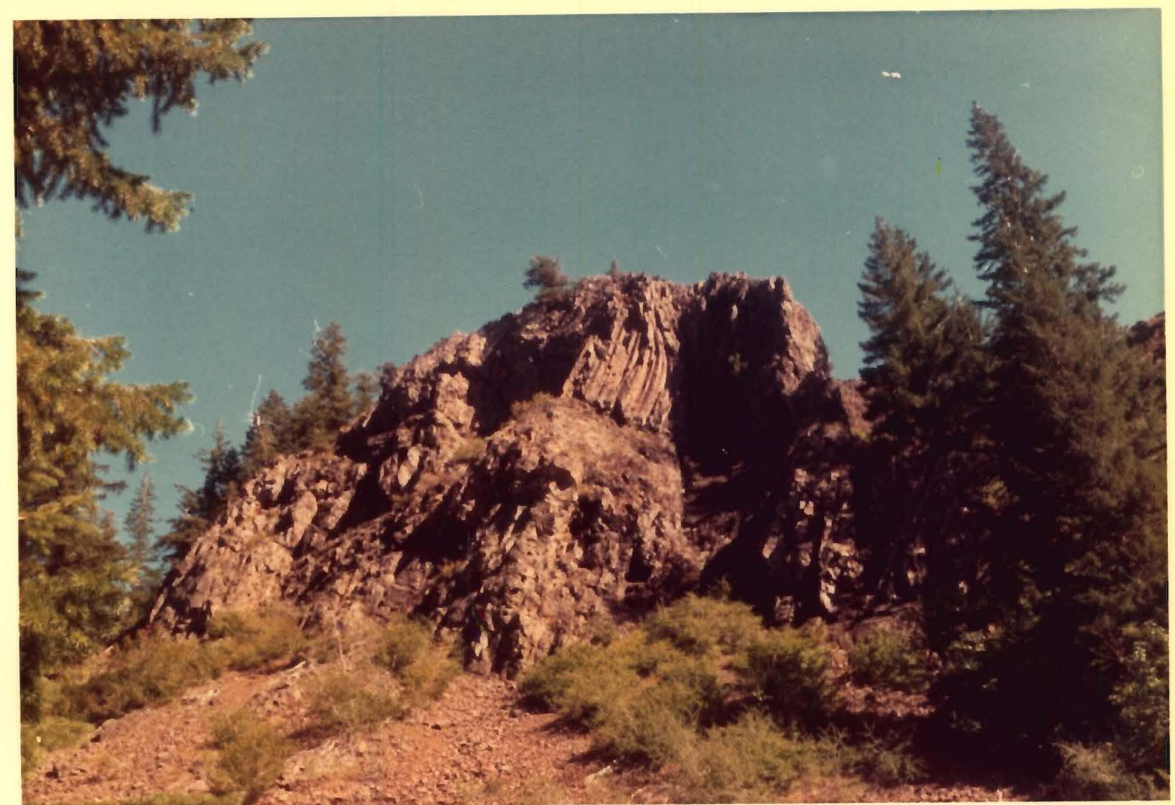

Figure 14. Columnar jointing in lava flow of the Teanaway Basalt. Exposure is along Kachess Ridge Trail (SW 1/4 SW 1/4 Sec. 25, T.2lN., R.13E.) 
(4,400 feet, measured in cross-section C, P1. 1) occurs on the west flank of the syncline. Regjonally, the Teanaway Basalt crops out in an arcuate band, up to 4 miles in width, that extends from Kachess Lake eastward some 28 miles to Table Mountain, and ranges in thickness from 1,000 to 5,000 feet (Foster, 1960).

\section{Contact Relations}

The Teanaway Basalt overlies the Silver Pass Volcanics with an angular unconformity of 30-35 degrees. The contact with the underlying rocks occurs in a deep, thickly vegetated ravine on the west side of Kachess Ridge (PI. 1), but is not exposed. On Cle Elum Ridge, north of Thomas Mountain (PI, 1), the Teanaway Basalt has been brought into contact with both the Silver Pass Volcanics and the Swauk Formation by the steeply southwest-dipping Thomas Mountain Fault (PI. 1). The relationships in this area are obscured by vegetation, and, as noted earlier (p. 9), this contact had previously been interpreted as an unconformity (Foster, 1960).

\section{Age and Correlation}

The Teanaway Basalt unconformably cverlies the Silver Pass Volcanics, of early Eocene age (p. 34). Outside the area, it is overlain concordantly by strata of the Roslyn Formation (Foster, 1960), which contains an Eocene flora 
(Smith and Calkins, 1906) and middle or upper Escene fauna (wheeler, 1955). The Teanaway Basalt is, therefore, considered to be early to middle Eocene in age. The Teanaway Basalt has not been correlated with volcanic strata of other formations, though Weaver (1937) believed that the rocks had been deposited during the same time interval as the Metchosin Volcanics of Western Washington. 


\section{Roslyn Formation}

\section{Introduction}

The Roslyn Formation, of midale or upper Eocene age, was named by Russell (1899) for the Roslyn coal-mining district near Roslyn, Washington. Approximately one square mile of rocks believed to be part of the Roslyn Formation is exposed in the extreme southeast corner of tho map area (Pl. 1), where it underlies the low, thickly woocied south end of Cle Elum Ridge.

\section{Eithology}

The strata of the Roslyn Formation consist of yellowish, coarse-grained, friable sandstone and interbedaed redaishorange siltstone and claystone. Rocks of these strata were not examined in thin section. In hand sample, the sandstone contains abundant quartz and feldspar, and is arkose. The siltstone and claystone are identified as such on the basis of their very fine grain-size, lack of fissility, and clayey odor when moistened. The layers of arkosic sandstone show both graded-bedding and cross-bedding, contain pebbles and carbonaceous debris at their base, and range from a few inches to several feet in thickness. The upper zones of the arkosic strata have been stained to a readish color by overlying layers of siltstone and claystone. These layers are generally less than one foot in 
thickness.

\section{Distribution and Thickness}

The Roslyn Formation cropis out along the southwest shore of Cle Elum Lake and forms the low, southern-most part of Cle Elum Ridge (PI. 1). The western slope of the ridge is believed to be the top of the Roslyn Formation strata, and the map thickness of the section occurring between the ridge crest and the shore of the lake (PI. 1, Line $\left.\mathrm{H}-\mathrm{H}^{\prime}\right)$ is 2,275 feet. Regionally, strata of the Roslyn Formation are best exposed along the forks of the Teanaway River, to the east of the map area (Foster, 1960), and attain a maximum thickness of 3,500 feet (Smith and Calkins, 1906).

\section{Contact Relations}

The Roslyn Formation, in the map area, is in faultcontact with strata of the Teanaway Basalt. The contact occurs in a stream-bed on the southwest shore of Cle Elum Lake (PI. 1). It is not exposed, and is interpreted as a fault on the basis of the abrupt change in attitude between Roslyn and Teanaway strata on opposite sides of the stream, and because of the trend of the contact, which is nearly at right angles to the general strike of beding in the two formations (PI. 1). The fault strikes northeast- 
southwest and has an estimated dip of 30-40 degrees southeast (PI. 1). The northwest-southeast trending contact in the valley of Domerie Creek (Pl. 1) is also believed to be a fault (Foster, 1960). On a regional scale, the nature of the contact of the Roslyn Formation with the underlying Teanaway Basalt is described by Foster (1960) as "controversial", and may either be conformable or unconformable.

\section{Age and Correlation}

No fossils were found in the Roslyn Formation during this investigation. An age of middle Eocene häs been suggested by Hesse (1936) on the basis of a fossil fish, and two fossil turtle carapaces, reported by wheeler (1955), indicate a middle or upper Eocene age for the Roslyn strata. Weaver (1937) believed the rocks to be upper Eocene in age, and, on the basis of the foregoing discussion, an age of middle or upper Eocene is here assumed for the Roslyn Formation. These rocks have not been chronologically or iithologically correlated with rocks of other formations. 
Howson Andesite

General Discussion

Several outcrops of gray porphyritic hornblende ardesite occur on the west slope of North Peak, near the top (Pl. 1). The rocks appear to unconformably overlie the North Peak Metavolcanics, which are believed to be of Mesozoic age (p. 18), though the contact between the two units is obscured by talus. The andesite is unaltered and appears similar in hand specimen to samples of the Howson Andesite, which crops out approximately 4 miles to the northeast on Sasse Mountain. The Howson Andesite was named and described by Smith and Calkins (1906), but was not assigned an age. Foster (1960) stated that the Howson Andesite is "apparentiy the youngest formation in this and the surrounding area."

\section{Iithology}

The andesite is greenish gray on the fresh surface and weathers to light gray. Phenocrysts of hornblende up to $3 \mathrm{~mm}$. in length are visible in hand specimen, as well as slightly smaller crystals of plagioclase. In thin section, the rock consists of 12 percent green, euhedral, zoned, and partially resorbed hornblende, 24 percent cloudy, complexly zoned plagioclase, and 64 percent matrix consisting of 
felted plagioclase microlites, interstitial quartz, brownish chlorite, and granular magnetite. In the outcrop, the andesite breaks into angular blocks, averaging about a foot in diameter, from which extensive talus slopes have developed.

Age

The age of the Howson Andesite cannot be precisely determined from relationships in the area. Foster (1960, P1. 1), however, shows the formation occurring stratigraphically above the Yakima Basalt of Mio-pliocene age, and on this basis, a tentative Pliocene age is assured in this report for the Howson Andesite. 


\section{STRUCTURAL GEOLOGY}

\section{General ReJations}

The most impcrtant structurai feature in the map area is the north-northwest trending Thomas Mountain fault (PI, 1), which approximately bisects the area and separates older, pre-Tertiary and Upper Cretaceous-Paleocene metamorphic and sedimentary rocks from younger Eocene volcanic and sedimentary rocks. Interlayered lava flows and pyroclastic rocks of the early Eocene Silver Pass Volcanics are exposed on both sides of the fault. North of Thomas Mountain fault, the structural trend is northwest, roughly paralleling the trends in Paleozoic and Mesozoic rocks of the North Cascades. The trend of the diabase aike swarm is northeasterly, nearly at right angles with that of the older rocks. South of Thomas Mountain fault, the older, northwesterly structural trend is reflected by Domerie Creek synciine, while the Silver Creek fault system (Pl. 1) is developed along a younger, northeasterly trend.

\section{$\underline{\text { Folding }}$}

Two major folds occur in the area, Thorp Mountain anticline, to the north of Thomas Mountain fault, and Domerie Creek synciline, south of the fault. According to the classification of Straley (1935, in Badgley, 1965), these are open, cylinarical, inclined, asymmetrical folds 
(see map and cross-sections, Pl. I). A Beta diagram of 12 Easton Schist $S_{1}$ (schistosity) planes, constructed on a Schmidt stereographic net (Fig. 15), suggests that the axis of Thorp Mountain anticline trends south 31 degrees east, plunging $i 0$ degrees. Domerie Creek syroline has a similar trend on the south side of the SiIver Creek fault (P1. 1). Oil the north side of the fault, the synclinal axis has a more northerly trend, and it is believed that rotational movement on the Silver Creek fault is responsible for the change in direction of the synciinal axis.

\section{Faulting}

The major fault in the area is the Thomas Mountain fault, which strikes north 63 degrees west and has an estimated dip of 70 degrees southwest. Movement on the fault has been predominantly vertical, the block on the south side having moved down with respect to the block on the north, although it is believed that some rotational movement, associated with movement on the Silver creek fault, has also occurred. Evidence for rotational movement is provided by the structural block containing Thomas Mountain, which is bounded on the north by Thomas Mountain fault and on the south by silver creek falit (PI. 1). The structural trend of this block is nearly north-south, while the structural trends of the adjoining north and south blocks are northwest-southeasterly, and rearly. 


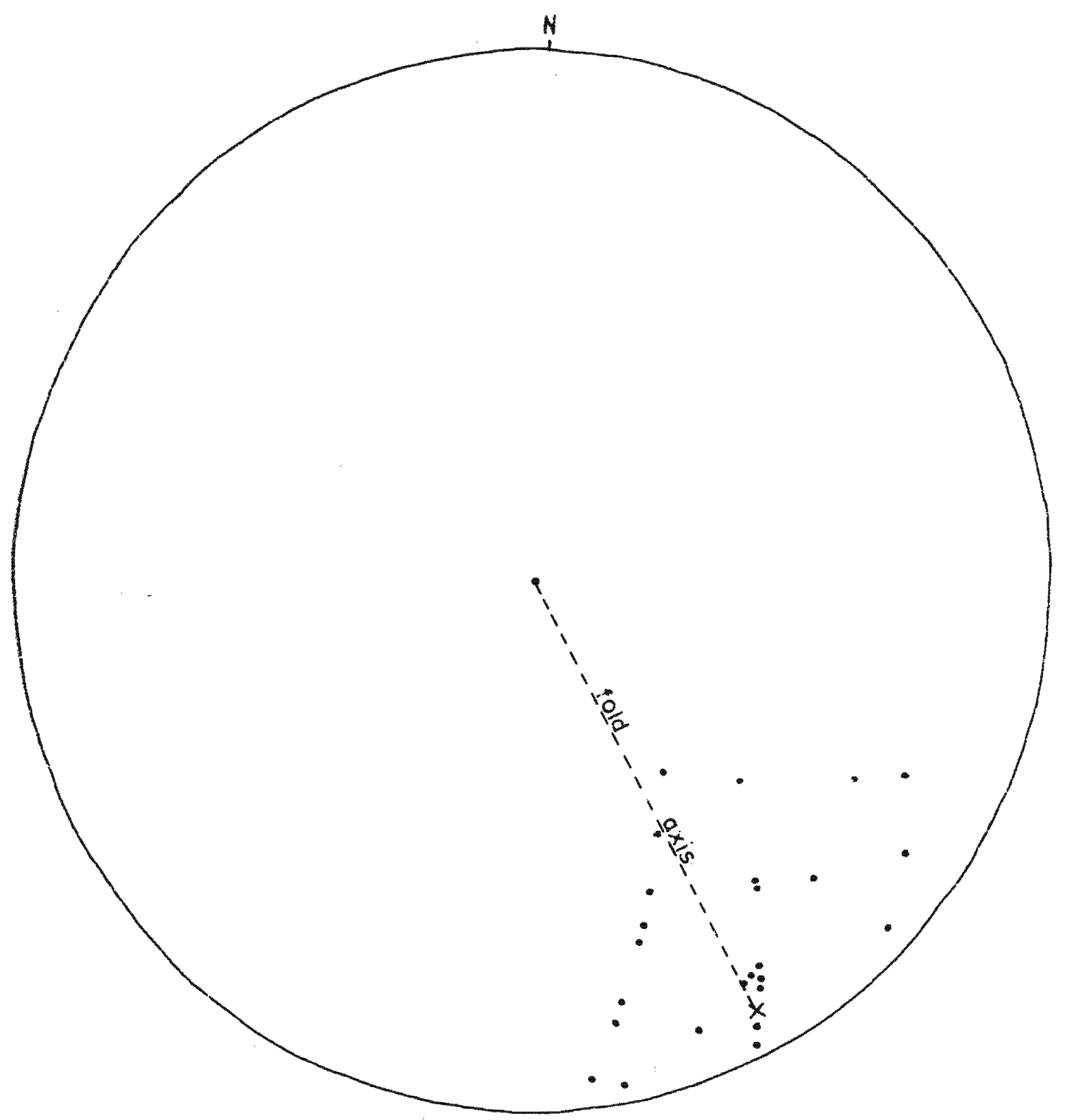

Figure 15. Beta diagram constructed from $12 \mathrm{sl}$ (schistosity) planes in the Easton Schist. Points indicate intersections of planes; " $X$ " (visually located at maximum point density) indicates intersection of fold axis with lower hemisphere of projection. Direction of fold axis is $531^{\circ} \mathrm{E}$, plunging $10^{\circ}$. 
parallel. These relationships are difficult to explain without the inferral of rotational movement.

The amount of displacement on the Thomas Mountain fault is not known. The significance of the fault in the interpretation of the contact relations between rocks of the Swauk Formation, Silver Pass Volcanics, and Teanaway Basalt, has been previously discussed ( $p .9$ ), and will not be repeated here. The fault has also complicated relationships at the north end of Kachess Ridge, where southwesterly dipping strata of the Silver Pasi Volcanics on the south flank of Thorp Mountain anticline, have been brought into contact, along strike, with oppositely dipping Silver Pass strata on the west flank of Domerie Creek syncline (PI. 1).

Three sub-parallel, northeast-trending faults occur to the south of Thomas Mountain fault. The most important of these is the silver Creek fault which dips approximately 30 degrees to the southeast and which, as noted earlier in the discussions of Domerie Creek syncline and Thomas Mountain fault, is believed to have undergone predominantly rotational movement. The movement has shifted the syricinal axis (in map section) from a direction of north 52 degrees west on the south side of the fault to a direction of north 16 degrees west on the north side of the fault (Pi. 1). The two faults to the south of the Silver Creek fault also have dips of approxinately 30 degrees to the southeast, but are apparently normal faults, the blocks on their south 
sides having moved vertically downward with respect to the blocks on their north sides. To the north of Thomas Mountain fault, the Kachess Ridge fault (Pl. 1) truncates flows of the Silver Pass Volcanics. This fault, like the Silver Creek fault, strikes northeasterly and dips to the southeast, and may have developed contemporaneously with the silver creek and other northeasterly striking faults. 


\section{GEOLOGIC HISTORY}

\section{Introduction}

Seven distinct rock units are recognized in the area. These, and the tectonic events associated with them, are summarized below, in order of decreasing age.

Sunmary of Rock Units and Tectonic Events

(1) The oldest rocks in the area are those of the Easton Schist. They form a basement of blueschist, greenschist, and graphite schist that was metamorphically derived from a eugeosynclinal assemblage of basaltic volcanic rocks and carbonaceous sedimentary rocks. The orcgeny which produced the Easton Schist probably occurred in late Paleozoic or early Mesozoic time (p. 14), and marks the beginning of deformational history in the area.

(2) A sequence of Eyrociastic rocks and limy sedimentary rocks was deposited upon the Easton Schist during the Mesozoic. Following their deposition, these rucks, along with the Easton Schist, were folded along a northwesterly trend, and the pyroclastic and sedimentary rocks were metamorphosed to marble and semiscrist, now recognized as the North Peak Metavolcanics. Most of these rocks were later removed by erosion, but a small mass, tightly folded with the Easton Schist (PI. I, 
cross-section $A-A^{\prime}$ ), is preserved at North Peak.

(3) During the late Cretaceous and Paleocene, arkosic sandstone of the Swauk Formation was deposited on the eroded surface of the Easton Schist. During or following this depositional phase, the Swauk formation and underiying Easton Schist were folded along the northwesterly trend established in the Easton Schist during the Mesozoic. Folding was accompanied by erosion, during which a part of the Swauk Formation was removed, and the Easton Schist was re-exposed in the area of French Cabin Basin.

(4) The Silver Pass Volcanics, consisting of interlayered lava flows and pyroclastic rocks, were deposited nonconformably on the Easton Schist and unconformably on the Swauk Formation during the early Eocene. The differences in bedding altitude between strata of the Silver Pass Volcanics and Swauk Formation are not great (PI. 1), and the attitudes suggest that strata on the flanks of Thorp Mountain anticline and Domerie Creek syncline probably dipped less than $20^{\circ}$ prior to the deposition of the Silver Pass Volcanics. Folding along the northwesterly trend continued, however, and bedding on the flanks of these folds had probably attained dips of about $35^{\circ}$ by the time the Silver Pass rocks had accumulated.

(5) Diabase dikes intruded the folded Easton Schist, 
Swauk Formation, and Silver Pass Volcanics during the early or middle Eocene. The dikes were emplaced along a northeasterly trend, approximately at right-angles to the northwesterly fold trend. The northeasterly trend of dike emplacement may have been related to the stresses responsible for the folding of the silver Pass and older rocks (Foster, 1960).

(6) Lava flows of the Teanaway Basalt were deposited unconformably on the Silver Pass Volcanics during the middle Eocene. The flows are exposed in the flanks of Domerie Creek syncline and have an average dip of $35^{\circ}$. The underlying Silver Pass strata, on the west flanks of both Domerie Creek syncline and thorp Hountain anticline, have dips averaging about $70^{\circ}$, suggesting that folding along the northwesterly trend continued during, or follcwing, the extrusion of the Teanaway Basalt. The present fold configuration was reached at some time following the deposition of the Roslyn Formation, of middie or late Eocene age. Strata of the Roslyn Formation are in fauit contact with the Teanaway Basalt and older rocks.

(7) Faulting occurred during, or following, the final phase of middle or late Tertiary folding. Thoras Mountain fault, the main structural element in the area, nearly parallels the northwest-trending fold axes (PI. I), and reflects the northwesterly structural trend established in the basement rocks during the Mesozoic. The Silver 
Creek fault, and the two faults to the south, have a northeasterly trend (PI. 1). This trend may reflect tira direction in which shearing stresses, associated with the formation of Thomas Mountain fauit, occlired in the basement rocks.

(8) The final phase of volcanic activity in the region occurred during the pliocene with the extrusion of the Howsor Andesite. Wost of these rocks were subsequently removed by erosion, and their original araal extent is not known.

(9) The voungest geological event recorded in the area is the formation of the deep basins now occupied by Lakes Cle Elun and Kachess. Glacial striations, such as those found on the west shore of cle Elum Lake, suggest that these basins were carved by valley glaciers, probably during the most recent period of Pleistocerie glaciation. 


\section{REFERENCES CITED}

Badgley, Peter C., 1965, Structural and tectonic principles: New York, harper and Row, Publishers, 521 p.

Erikson, E.H., 1973, Degranitization of the iate Cretaceous Mt. Stuart Batholith, Central Cascades, washington: Geol. Soc. America Abs. W. Programs, V. 5, no. 1, p. 39 .

Foster, R.J., 1958, Teanaway dike swarm, Central Washington: Am. Jour. Sci., v. 256, p. 644-653.

1960, Tertiary geology of a portion of the Central Cascade Mountains, Washington: Geol. Soc. America Bull., v. 71, p. 99-126.

Hesse, C.J., I936, A rew species of the genus Priscarara from the Eocene of Washington: Jour. Geology, V. 44, p. $745-750$.

Hyndman, DoraId W., 1972, Petrology of igneous and metamorphic rocks: New York, MCGraw-Hill, Inc., 533 .

Mckee, Bates, 1972, Cascadia - The geologic evolution of the Pacific Northwest: New York, McGraw-Hill, Inc. $394 \mathrm{p}$.

Misch, P., 1959, Sodic amphiboles and metamorphic facies in Mount Shuksan belt, Northern Cascades, Wash. (Abst.): Geol. Soc. America Bull., v. 70, p. 17361737 .

1966, Tectonic evolution of the Northern Cascades of Washington State - A west-cordilleran case history, in Gunning, H.C., ed., A symposium on the tectonic history and mineral deposits of the western cordiliera in British Columbia and neighboring parts of the United States: Canadiar Inst. Minirg and Metallurgy Spec. v. 8, p. I0I-148.

Ragan, Donal M., 1968, Structural geology - An introauction to geometrical techniques: New York, John Wiley and Sons, Inc., $166 \mathrm{p}$.

Russel, I.C., 1893, A geologic reconnaissance in Central Washington: U.S. Geol. Survey, Bull. 108, 108 p. 
, 1899, Geology of the Cascade Mountains in Northern Washington: U.S. Geol. Survey, 20 th Ann. Rept., pt. 2, p. 83-310.

Smith, G.0., 1903, Contributions to the geology of Washington: The geology and physiography of Certral Washington: U.S. Geol. Survey Prof. Paper 19, p. 9-39. , 1904, Description of the Mount Stuart quadrargle [Wash.] : U.S. Geol. Survey, Geol. Atlas, Mount stuart folio (no. I06), $10 \mathrm{p}$. , and Calkins, F.C., 1906, Description of the Snoqualmie quadrangle [Wash.]: U.S. Geol. Survey, Geol. Atlas, Snoqualmie folio (no. 139), 14 p.

Stout, Martin L., 1964, Geology of a part of the SouthCentral Cascade Mountains, Washington: Geol. Soc. America Bull., v. 75, p. 317-334.

Weaver, C.E., 1937, Tertiary stratigraphy of Western Washington and Northivestern Oregon: Univ. Wash. Pubi. Geol., v. 4, p. 1-256,

Wheeler, H.E., 1955, Dermatemiaid turtle from the Roslyn Formation of Washington (Abst.): Geol. Soc. America Buil., v. $6 \tilde{6}$, p. 1668 .

Williams, H., Turner, F.J. and Gilbert, C.M., 1954, Petrography: San Francisco, S.A. Freeman and Co., $406 \mathrm{p}$. 
APPENDIX A

LOCATION AND HAND-SPECIMEN DESCRIPTION OF SAMPLES EXAMINED IN THIN SECTION. SEE ALSO LOCATION MAP, FIGURE 4, AND FETROGRAPHIC SUMMARIES, TABILES I AND II AND APPENDICES B-E.

Formation

Description and rocation

Eastor Schist

$\operatorname{ESB}(1-3)$

Glaucophane epidote blueschist, south side of French Cabin Creek Roac., SE $1 / 4 \mathrm{SW} 1 / 4$ Sec. 2, T2IN, R13E. Three thin sections.

$\operatorname{ESG}(1,2)$

C.inozoisite chlorite greenschist, steep cliff 100 yaras east oj bridge actoss French Cabin Creek, NE 1/4 NE 1/4 Sec. 2, T21N, R13E. Two thin sections.

North Peak Metavolcanics

NPKI

Welded lapilli tuff, peak of North Peak, French Cabin Mountain, $S$ I,'2 SW 1,'4 Sec. I, T2IN, RI3E. One tinin section.

$\operatorname{NPK} 2(1,2)$

Chloritic semischist, saddle between North and South Peaks, Frerch Cabin Mountain, S 1/2, NW 1/4 Sec. 12, T21N, RI3E. Two thin sections.

Silver Pass Volcanics

SP 6W

SP $5 W$

SP $4 W$

SP $3 W$
Black, aphanitic andesite, crestline of Kachess Ridge, SE $1 / 4$ SW 1/4 Sec. 10, $\mathrm{T} 21 \mathrm{~N}, \mathrm{R} 13 \mathrm{E}$. One thin section.

Olive green, porphyritic andesite, $500 \mathrm{yd}$. NW of SP6W, along ridge crest. Cne thin section.

Light gray green crystal lithic lapilli tuff, $300 \mathrm{yd}$. NW of SP 5 , along ridge crest. One thin section.

Highly altered, greenish black, porphyritic hornblerde andesite, $200 \mathrm{yd}$. N. of SP4W, along ridge crest, Kachess Ridge. One thin section. 
APPENDIX A (CONTINUED)

Formation

Description and Location

Silver Pass Volcanics

$\operatorname{SP} 2 \mathrm{~W}(1,2)$

Brownish white, highly weathered andesitic flow rock above readish-brown hornblende andesite, on $\mathrm{E}$. side of Kachess Ridge, 150 yd. NE and downill from SP $3 w$. Two thin sections.

$\operatorname{SPIW}(1-3)$

$\operatorname{SPOW}(1-5)$

Jpper hornblende andesite flow, middle aphanitic andesite flow, and lower hypersthene andesite flow, forming prominent peak to west of saddle at Silver Pass, French Cabin Creek Trail, NE 1/4 NW 1/4 Sec. 10, T2IN, RI3E. Three thin sections.

$\operatorname{SPIE}(1,2)$

SF $2 E$

upper green, arystal lithic lapilli tưf and lower white crystal lithic lapilli tuff, exposed west of trail at siiver pass and east of sharp peak formed by SPIW. Five thin sections.

SP $3 E$

Upper porphyritic hornblende andesite flow and lower aphanitic hornblende andesite flow, forming peak directly east of trail at Silver Pass, NW 1/4 NE 1/4 Sec. 10, T2IN, Rl3E. Two thin sections.

Green, crystal lithic tuff, possibly water-lain, forming unit $120 \mathrm{ft}$. thick beneath flows of SPIE, $300 \mathrm{yd}$. E. Of trail at Silver Pass. One thin section.

SP $4 E$

Red, Iithic lapilli tuff below SP2E. One thin section.

Light yellow, highly amygdaloidal flow rock, NE side of knob to NW of West Peak, NW $1 / 4 \mathrm{SW} 1 / 4 \mathrm{Sec} .11, \mathrm{~T} 2 \mathrm{IN}, \mathrm{R} 13 \mathrm{E}$. One thin section.

SP 5E

Olive green crystal tuff, west side of West Eeak on dip slope, SE $1 / 4$ SW $1 / 4$ Sec. 1l, T2lN, R13E. One thin sectior. 
APPENDIX A (CONTINUED)

Formation

Description and Location

Silver Pass Volcanics

SP $6 E$

Similar to SP5E, from outcrops near peak of West Peak, Frerch Cabin Mountain. One thin section.

SP 7E

Bluish green aphanitic andesite, NE side of West Peak, probably below flows SP5E and SP6E. One thin section.

SP 8E

Dense, black aphanitic flow rock, 100 ya. $E$. of SP7E, NE side of West Peak. One thin section.

$\operatorname{SP9E}(1,2)$

SP 53

Upper green, aphanitic andesite and lower. light green, water-iain crystal tuff or volcanic sandstone, $N$. side of Domerie Peak Trail, on ridge between west and South Peaks, NW 1/4 NW 1/4 Sec. 13, T2lN, R13E. Two thin sections.

Highly weathered, rhyolitic andesite flow, W. shore of Cle Elum Lake, NW $1 / 4$ SW $1 / 4$ Sec. 20, T2IN, RI4E. One thin section.

SP 32

Green, crystal lithic tuff identical to SP2E, $300 \mathrm{yd}$. S. of SP53, near mouth of creek, SW $1 / 4$ SW $1 / 4$ Sec. 20 , T2IN, RI4E. One thin section.

Teanaway Basalt

TB1

Dense, black aphanitic basalt, $300 \mathrm{yd}$. S.E. of beacon, S. end of Kachess Ridge, NW 1/4 SE 1/4 Sec. 26, T $21 \mathrm{~N}$, R.13E.

TB 4

Greenish-black, vesicular, aphanitic basalt, 400 yd. S. of TBI at break in slope, $S$. end of Kachess Ricige.

TB5

Black, aphanitic basait, 500 yd. S. of TB4, midway between top and bottom of Kachess Ridge. 
APPENDIX A (CONTINUED)

Formation

Description and Location

Teanaway Basait

TB6

Green, vitric lithic lapilli tuff, $300 \mathrm{yd}$. S. of, and down-slope from, TB5, S. end of Kachess Ridge.

TB7

Black, aphanitic basalt, $400 \mathrm{yd}$. SW of, and downslope from, TB6, near base of Kachess Ricge, SW 1/4 NE 1/4 Sec. 35, $\mathrm{T} 21 \mathrm{~N}, \mathrm{R} 13 \mathrm{E}$.

TBDPKP

Highly altered, vitric crystal lithic tuff, on Domerie Peak trail, $600 \mathrm{yd}$. NW of peak of Mt. Baldy, NW $1 / 4 \mathrm{NW} 1 / 4 \mathrm{Sec}, 31$, $\mathrm{T} 21 \mathrm{~N}, \mathrm{RI} 4 \mathrm{E}$.

TBMT

Dark gray, zlassy, vesicular flow rock, W. slope of Cle Elum Riäge, iNE $1 / 4 \mathrm{SW} 1 / 4$ Sec. 24, T2IN, RI3E.

Diabase Dike Swarm

DDI

Gray coarsely crystalline diabase dike, W. side of logging road, $\mathrm{NE} 1 / 4 \mathrm{Sec}$. 18 , T21N, RI4E.

Howson Andesite

$\mathrm{HA} 1$

Porphyritic hornblende andesite, on ridge $500 \mathrm{yd}$. S. of top of North Peak, NW $1 / 4$ NW $1 / 4$ Sec. I2, T2IN, RI3E. One thin section. 
Appendix B, Summary of Petrography of Easton Blueschist

\begin{tabular}{|c|c|c|c|c|c|}
\hline Mineral & Glaucophane & Epidote & Chlorite & Quartz & Plagioclase \\
\hline Modal $8 *$ & $6-23$ & $58-78$ & $3-11$ & $6-9$ & $\mathrm{~T}$ \\
\hline Pleochroism & $\begin{array}{l}\text { strong; } \mathrm{x}= \\
\text { neutral, } \\
\mathrm{Y}=\mathrm{violet}, \\
\mathrm{Z}=\text { blue }\end{array}$ & $\begin{array}{l}\text { slight; shades } \\
\text { of green, yel- } \\
\text { low-green }\end{array}$ & $\begin{array}{l}\text { strong; neu- } \\
\text { tral to green }\end{array}$ & & \\
\hline Optic Angle & $\left(-145^{\circ}\right.$ & $(-) 80$ & ma 11 & & undetermined \\
\hline $\begin{array}{l}\text { Birefrin- } \\
\text { gence }\end{array}$ & undetermined & strong, .03 & $\begin{array}{l}\text { extremely } \\
\text { weak }\end{array}$ & & \\
\hline Grain size & $.1 \mathrm{~mm}$ & variable & variable & vaxiable & variable \\
\hline Occurrence & $\begin{array}{l}\text { lenticular } \\
\text { bands }\end{array}$ & $\begin{array}{l}\text { segregation } \\
\text { layers }\end{array}$ & $\begin{array}{l}\text { veins; with } \\
\text { epidote and } \\
\text { giaucophane }\end{array}$ & $\begin{array}{l}\text { veins; } \\
\text { lenticular } \\
\text { bands with } \\
\text { pc }\end{array}$ & $\begin{array}{l}\text { lenticular bands } \\
\text { with quartz }\end{array}$ \\
\hline Texture & $\begin{array}{l}\text { nematoblas- } \\
\text { tic }\end{array}$ & granoblastic & granoblastic & $\begin{array}{l}\text { granoblas- } \\
\text { tic }\end{array}$ & $\begin{array}{l}\text { granoblastic, } \\
\text { untwinned }\end{array}$ \\
\hline $\begin{array}{l}\text { Additional } \\
\text { notes }\end{array}$ & $\begin{array}{l}\text { Granular sphene } \\
\text { present as acces }\end{array}$ & $\begin{array}{l}\text { and lesser arnou } \\
\text { ssories. }\end{array}$ & nts or paxtially & oxidized & agnetite are \\
\hline
\end{tabular}




\section{Appendix C, Summary of Petrography of Easton Greenschist}

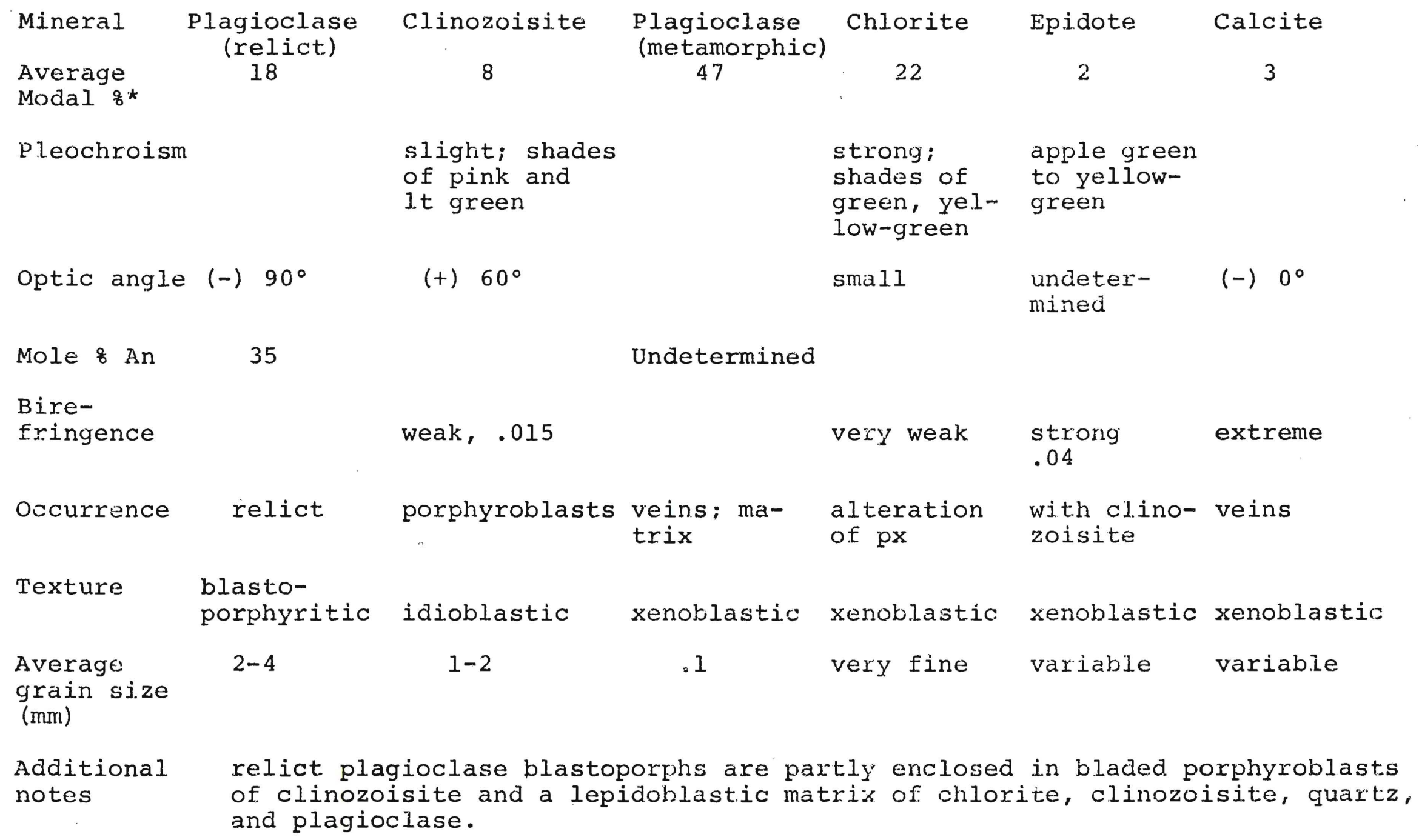

* Point count of $l$ thin section 
Appendix D: Petrographic Summary of Silver Pass Volcanics, Part I

ROCK TYPE

APHANITES

Topographic

Expression

Color Fresh

Color

Weathered

Grain Size

Crystal-

linj.ty

Textures sharp hogbacks and rims

dark gray to black, light brown or gray

fine, . $1 \mathrm{~mm}$

merocrystalline to holocrystalline

pilotaxitic, trachytic, felted, hyalopilitic;

may be amygdaloidal, spherulitic, or axiolitic

\section{PORPHYRTTIC APHANITES}

steep slopes and cliffs

greenish gray, greenish

brown, brown, yellowbrown

fine matrix; $1-3 \mathrm{~mm}$ phenocrysts

holocrystalline

pilotaxitic, trachytic, cryptocrystalline
PYROCIASTIC ROCKS

smooth, gentle slopes

purple, red, green, light green, light grä

tuffs, lapildituffs, tuff-breccias

none

pourly sorted, angulax lithic fragments, usially with pilotaxitic or vitroclastic textures, and broken, euhedral crystals in a claylike matrix 


\section{Appendix D, cont.: Petrographic Summary of Silver Pass Volcanics, Part II}

ROCK TYPE

APHANTTES

PORPHYRITIC APHANITES

PYROCLASTIC ROCKS

\section{MINERALOGY and AVERAGE MODAL COMPOSITION}

29-59\%* fresh to highly weathered, subhedral to euhedral, twinned, zoned (An 38-An64) plagioclase phenocrysts averaging .5 mm to $1 \mathrm{~nm}$ in length; 0-22\% subhedral to euhedral phenocrysts of green or greenish-brown hornblende averaging $.5 \mathrm{~mm}$ in length and altering in part to chlorite and magnetite; 0-35\% calcite and epidute occurrirg in irregular patches in the matrix and as an alteration product of plagioclase äd pyroxenes; 0-35\% orthopyroxene microlites; 0-6\% ragnetite, and 13-97\% matrix consisting of plagioclase microlites, granular pyroxene, and yellow to green, weakly to moderately birefringent material believed to be clay.

6-22\%* subhedral to euhedral, zoned (An32-4n50) phenocrysts of plagioclase, highly corroded and embayed and altered entirely or in part to calcite and/or quartz, average length of phenocrysts $3 \mathrm{~mm}$; 0-5\% clinopyroxene phenocrysts averaging $.25 \mathrm{~mm}$ to $\mathrm{I} \mathrm{mm}$ in length, altered in some rocks to yellowgreen, clay-like aggregates and bordered at grain edges in some rocks by orthopyroxene or magnetite; $0-12 \%$ twinned, weakly pleochroic orthopyroxere; 0-4\% hornblende, in part resorbed or altered to inagnetite and chlorite, occasionally oxidized; 0-lo calcj.te and epidote developed along cleavages and fractures in plagioclase crystals, and as patches, veins, and stringers; 0-1. matrix, consisting of cryptocrystaline quartz, feldspar, and possibly clay minerals.

14-17\%*** 1ithic Eragments, mostly volcanic and having vitroclastic or pilotaxitic textures, and containing plagioclase phenocrysts ranging from An 36 to An54; 10-21告 fresh, broken crystals of plagioclase ranging from An25 to An40; 0-2\% broken, angular quartz fragments, and 60-76\% unresolvable, greenish-colored, weakly birefringent matrix.

* Range of 4 thin sections point-courted 500 points each

** Range of 4 thin sections point-counted 500 points each

** Range of 3 thin sections point-counted 500 points each 


\section{Appendix E, Part 1: Petrography of Teanaway Basalt Flow Rocks}

Color

Grain size

Crystallinity

Matrix

Mineralogy

pyroxene

magnetite

quartz

glass

hematite

calcite

other glassy black when fresh; shades of gray, brown, and red-brown when weathered

very fine, aphanitic; crystals average less than $.25 \mathrm{~mm}$ in diameter generally mercorystalline, but some flows are holocrystalline

intergranular or intersertal texture with pyroxene, plagioclase microlites, magnetite octahedra, and interstitial glass, clay minerals (?), and chlorophaeite (?)

Modal $\frac{8}{0}$ *

Distinguishing Features

$11-51$

clear to very pale green, non-pleochxoic, and order interference colors

35-54 zoned microlites (An39-An55) of random orientation

3-17 corroded rods and euhedral octahedra

0-10. anhedral intergrowths with plagioclase

0-18 interstitial and amygdaloidal; yellow, brown, brownish-green

T blood-red borders around magnetite

0-5 random pools and veins throughout some flows

$T$ yellow, brown, or green materials believed to be clay Ininerals or chlorophaeite

* Range of 3 thin sections point-counted, 300-500 points each. 


\section{Appendix E, Part 2: Petrography of Teanaway Basalt Pyroclastics}

\section{Color}

Fragment size

Fragment nature

Matrix

Mineralogy

Lithic

Vitric

Crystal

Matrix

dull green to mottled red and green; fragments may be green, red, purple, or brown

less than $1 \mathrm{~mm}$ to several centimeters, average about .5 centimeter

highly angular, poorly sorted lava fragments, vitric fragments, and broken crystals

optically unresolvable matrix believed to be a clay mineral (possibly halloysite) with minor amounts of calcite, hematite and quartz, often difficult to distinguish between matrix clastic materials

$10-59$

Modal $\frac{8}{8} *$

$37-90$

$$
0-90
$$$$
1059
$$

\section{Distinguishing Features}

textures often obliterated by alteration, but where preserved appear to be cryptofelsitic, with minute feldspar microlites intergrown with quartz; mafic minerals not distinguishable; alteration products probably clay (smectite?)

vitric fragments are pumicious with vesicles filled with green palagonite (?), growths of quaxtz and plagioclase, calcite, or opal; fragments usually stretched and flattened with arcuate shards trailing off into matrix

crystal fragments, when present, consist of unaltered, poorlysorted angular chips of quartz and untwinned plagioclase averaging $.5 \mathrm{~mm}$ in length

much of matrix consists of light, orange-brown, cryptccrystalline material which is cark gray, nearly isotropic under crossed-nicols, and is tentatively identified, on the basis of extremely weak birefringence (.001) and shatter-cracks, as halloysite.

* Range of 3 thin sections, 1 point-cointed, 2 visually estimatea 